\title{
VAT Compliance, Trade, and Institutions
}

\author{
May 2020
}

\author{
Peter Morrow \\ University of Toronto \\ Michael Smart \\ University of Toronto \\ Artur Swistak \\ International Monetary Fund
}

Working paper | 2019-2020

This working paper is authorised or co-authored by Saïd Business School faculty. The paper is circulated for discussion purposes only, contents should be considered preliminary and are not to be quoted or reproduced without the author's permission. 


\title{
VAT Compliance, Trade, and Institutions*
}

\author{
Peter Morrow \\ University of Toronto
}

Michael Smart

University of Toronto

Artur Swistak

International Monetary Fund

May 10, 2020

\begin{abstract}
We develop a simple model of value added tax (VAT) compliance, and estimate it using widely available national accounts data to learn about compliance in countries where little is currently known. International border controls improve VAT compliance, generating a correlation between imports and aggregate VAT revenues that is informative about domestic noncompliance. Estimates suggest that revenue lost due to domestic non-compliance is large, particularly in countries with low perceived institutional quality. We analyze how our estimates are related to institutional differences among countries, and discuss the implications for tax policy.
\end{abstract}

${ }^{*}$ Thanks to Youssef Benzarti, Richard Bird, Will Boning, Dhammika Dharmapala, Eric Hutton, Mick Keen, Wojciech Kopczuk, and Joel Slemrod, as well as participants as the World Bank-OTPR Conference on Value-added of ValueAdded Taxes and the National Tax Association's 111th Annual Conference on Taxation for comments and suggestions. The views expressed in this paper are the authors' and do not necessarily reflect the views of the International Monetary Fund. 


\section{Introduction}

Tax revenue mobilization is important for economic development, particularly in countries with low levels of state capacity (Besley and Persson, 2011, 2014). The value added tax (VAT) is a large and growing source of government revenue in most countries of the world 1 Consequently, understanding patterns of VAT compliance is important for thinking about revenue mobilization and economic development. The VAT is controversial, and some scholars have argued that its introduction has encouraged business informality, reduced government revenues, and hampered economic development. Unfortunately, the literature has not produced extensive or reliable estimates of noncompliance that can be used in explaining differences in revenue across countries with this lack of availability being particularly acute for low-income countries where fiscal capacity is potentially a major hurdle for state development.

In this paper, we develop a simple model of value added tax compliance, and we estimate it using widely available national accounts data for a large panel of countries. The key to our approach is the observation that VAT compliance is generally much higher for imports than for domestic production because existing border controls permit a high level of VAT enforcement in virtually all countries. When there is non-compliance in the domestic economy, it follows that an increase in the share of imports in consumption will be associated with an increase in VAT revenues. In contrast, when there is full domestic compliance, the model predicts no association between imports and VAT revenues as a share of consumption. Therefore, the relationship between the share of imports in consumption and VAT revenue is informative about the extent of domestic non-compliance.

The role of imports and border controls in enforcing VAT has long been recognized in the literature..$^{2}$ Indeed, the apparent difference between VAT compliance for imports and domestic production led Emran and Stiglitz (2005) to argue that VAT is a less productive and efficient tax than the trade taxes it has replaced in many countries around the world. 3 Non-compliance is a particular concern in low-income countries, if it creates incentives for business informality that reduces productivity 4 But the previous literature has not examined how differential VAT compliance for imports and domestic production can be used to recover estimates of the level of aggregate non-compliance. It is generally understood that VAT compliance is higher at the border; using our

\footnotetext{
${ }^{1}$ Based on IMF data discussed in Section 3 below, VAT accounts for 20 percent of tax revenues on average in OECD countries, and a higher share in many low and middle-income countries. VAT revenues exceed revenues from both individual income taxes and trade taxes in a majority of countries in the IMF data.

2 Ebrill et al. (2001).

${ }^{3}$ Emran and Stiglitz develop a theoretical model to argue that that VAT may have stronger effects than tariffs on informality in the domestic economy, and argue "these results raise serious doubts about the wisdom of the indirect tax reform policies pursued by a large number of developing countries." See however the discussion and contrasting views in Keen (2007) and Baunsgaard and Keen (2010).

4See, e.g., Piggott and Whalley (2001); Keen (2008); De Paula and Scheinkman (2010); Bird and Smart (2014).
} 
approach, we offer evidence that supports this stylized fact:5 Additionally, under the identifying assumption of perfect border compliance, we are able to recover estimates of domestic compliance for a range of countries $]^{6}$

The starting point for our approach is C-efficiency, a widely available metric of VAT revenue performance, defined as the ratio of revenues to that which would theoretically be collected by applying the standard statutory VAT rate to aggregate final consumption expenditures (Ebrill et al. 2001). As shown by Keen (2013), measured C-inefficiency of VAT can be decomposed into (i) the compliance gap, and (ii) the policy gap:7 The compliance gap is the percentage loss in revenues, at given VAT rates, that results from non-compliance by domestic taxpayers. The policy gap is the percentage loss in revenues (or "tax expenditure") resulting from deliberate policy choices, such as reduced VAT rates that are applied to certain goods and services.

While C-efficiency in almost all countries is less than 100 percent, the separate contributions of the compliance and policy gaps are generally not identified without additional data. This paper disentangles the two using panel data on national accounting aggregates. We regress C-efficiency on the ratio of imports to aggregate consumption. The slope of this relationship is informative about domestic non-compliance: the more domestic non-compliance, the more strongly related the import-ratio and C-efficiency will be in the data. As we show below, the reduced form parameters from such a regression can be used to recover separate estimates of the compliance and policy gaps.

To illustrate the method, Figure 1 shows the relationship between C-efficiency and the import ratio for two countries: Peru (the left panel) and Canada (the right panel). In Peru, there is a strong and positive correlation between the two series (correlation coefficient: 0.93). Imports rose sharply as a percentage of consumption in the early 2000s, and VAT revenues relative to consumption rose contemporaneously. In an idealized VAT with full compliance on domestic sales, the rise in imports would be irrelevant to revenues: VAT charged on imported business inputs would be refunded on final sales, and taxable imports of final consumption goods would merely displace taxable domestic final sales, leaving net VAT revenues unchanged. Thus the rise in VAT revenue C-efficiency with imports is indicative of higher VAT compliance at the border than on domestic sales. Based on our model and the estimation procedures described below, we estimate that the domestic VAT compliance gap for Peru is 62.8 percent. Next, consider the corresponding data

5 Keen (2008) constructs a theoretical model of how VAT collected at the border affects domestic informality, which offers a new perspective on the policy debate in Emran and Stiglitz (2005) and Keen (2007). Ebrill et al. (2001) and Keen and Lockwood (2010) both estimate the determinates of VAT revenues in cross-country panel data. These studies control in regressions for a country's openness to trade (defined as average share of exports and imports in GDP). But they do not focus on import compliance or give it a structural interpretation.

${ }^{6}$ In our model, we do not rule out the possibility of international smuggling that leads to VAT evasion. Instead, our identifying assumption is merely that VAT is always paid for the formal import transactions that are actually measured in the balance of trade and national accounts data. This assumption seems innocuous in most countries.

7 Unlike this paper, Keen (2013) does not directly estimate the compliance gap. 
Figure 1: Imports and VAT revenues in Peru and Canada
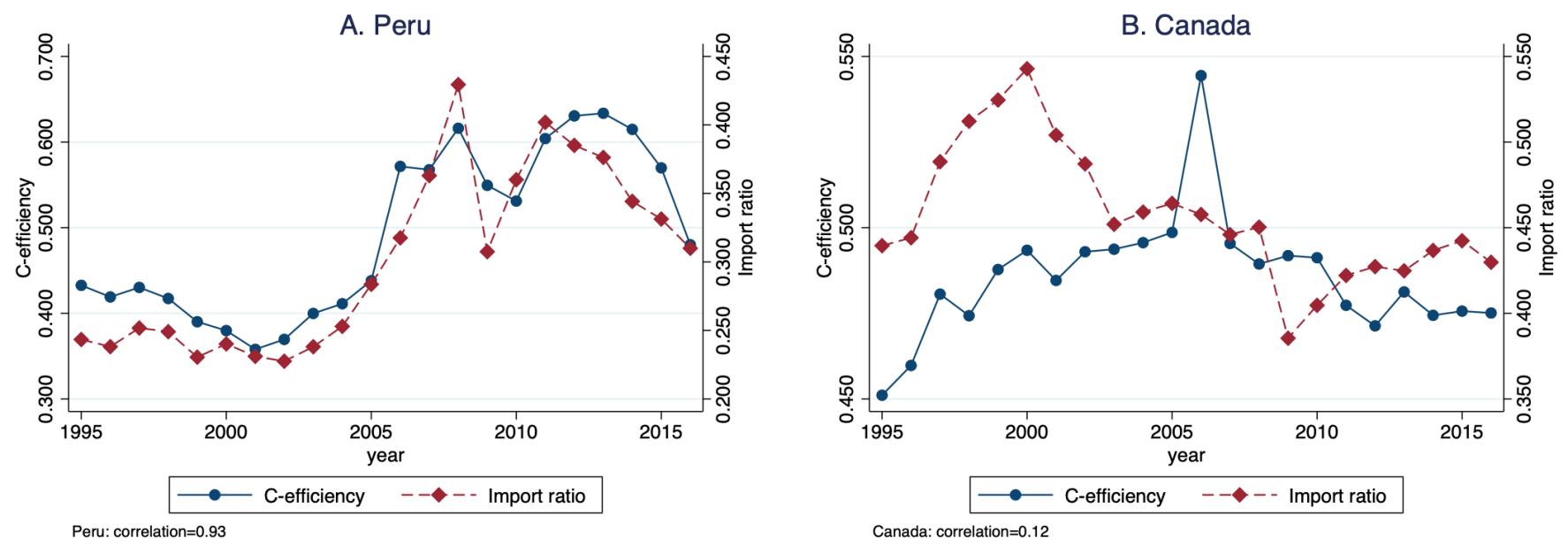

for Canada, depicted in the right panel. The overall level of C-efficiency is similar to Peru, but this could reflect VAT policy differences, rather than any underlying difference is compliance behaviour. More informative-and key to our approach-there is no visible relation between C-efficiency and the import ratio in the data for Canada: the partial correlation coefficient is 0.12 , and we obtain an estimated domestic compliance gap of 9.4 percent which is insignificantly different from zero. 8 This suggests that C-inefficiency is driven more in Peru by the compliance gap, and in Canada by the policy gap.

This difference between Peru and Canada is consistent with expectations. We measure country institutional quality by the World Bank Worldwide Governance Index (WGI) for the Control of Corruption (Kaufmann et al. 2009). Previous research has shown that the corruption perception metrics proxy for state and civil society factors that are conducive to tax non-compliance (e.g. Dharmapala and Hines, 2009; Besley and Persson, 2014). Peru lies in the 31st percentile of corruption control while Canada is in the 9oth percentile. Although this is surely an imperfect measure, our prior is that Peru will have more problems with VAT enforcement than does Canada.

Our empirical results below extend this example in several directions. Imports play a large and significant role in explaining differences in VAT revenue performance across countries and over time. In our unbalanced panel of 74 countries observed in the 1991-2016 period, imports are strongly related to revenues in some regions of the world and in countries with lower levels of perceived institutional quality. Based on our structural model, estimated domestic compliance gaps are small and statistically insignificant for Northern European countries, Australia, New Zealand, Japan, and Canada, but are as high as 50 percent or more of potential revenues in certain African,

\footnotetext{
${ }^{8}$ The Canadian government's own estimate of the VAT compliance gap, based on top-down accounting methods, is 7.8 percent (Canada Revenue Agency, 2016).
} 
Central Asian, and Latin American countries.9

There are substantial differences in estimated compliance gaps among countries, which may reflect differences in economic structures of countries, tax morale of citizens, or tax design and enforcement activities of governments. Several theories have been advanced in the literature to explain how such factors affect tax compliance. To shed light on existing theories, we analyze statistical associations between our gap estimates and measures of economic structures and institutions at the country level. Of course, these cross-sectional patterns cannot be taken as evidence of any causal links between compliance and institutional quality among countries, given concerns about omitted factors and reverse causality, but they nevertheless help to elucidate existing theories about determinants of tax compliance. Notably, controlling for countries' overall economic development, we find no relation between estimated gaps and the turnover threshold below which firms are exempt from VAT, nor with measures of the cost of starting a new business. In this sense, our estimated gaps do not merely reflect non-payment of tax by small firms that are exempt from VAT as a matter of policy. Indeed, our results suggest that higher regulatory frictions for business, such as compliance burdens for international trade and domestic asset transactions, are associated with lower rates of VAT non-compliance. While the result is surprising, it may reflect the way regulatory frictions that raise business costs are nevertheless useful to governments in enforcing tax laws. At the same time, we find that our gap estimates are negatively related to countries' level of financial development, as measures by the share of domestic credit in GDP. This is finding is consistent with theories of tax compliance that emphasize the informational role of financial intermediaries in ensuring tax compliance (Gordon and Li, 2009).

Our results also point to the importance of international trade in making VAT an effective tax. While estimated domestic compliance gaps are large in some countries, aggregate revenue losses are lower because of the high proportion of VAT collected at the border. On average, the aggregate compliance gap is roughly 66 percent lower than the gap for consumption that is sourced domestically. For countries that source consumption from abroad more than average, this difference is larger and, for countries that source consumption relatively more domestically, the gap is smaller $\left[{ }^{10}\right.$ But, while border controls keep revenues high in the presence of domestic non-compliance, the implications for efficiency and economic incidence are substantial. Rather than operating as a tax on domestic consumption as in the standard textbook model, in many countries in our sample, VAT operates much like a tax on imports, including imported intermediate inputs, together with a production subsidy to non-compliant domestic firms. In this sense, our results are consistent with

${ }^{9}$ To benchmark our estimates, we compare them to gaps computed using accounting methods discussed below, for European countries where detailed input-output accounting data are available (Barbone et al. 2013). Our estimates for European countries are very similar.

${ }^{10}$ When all consumption is sourced domestically, there is no difference between the domestic compliance gap and the aggregate compliance gap. 
the concerns about trade liberalization-cum-VAT reforms in low-income countries raised by Emran and Stiglitz (2005).

In all, our results point to an unexpectedly large compliance gap in some countries, to the important role of border controls in controlling non-compliance, and to the statistical power of our proposed technique in detecting non-compliance from widely available national accounting time series data.

\subsection{Institutions and previous literature}

VAT operates as a tax on final consumption expenditures similar to a retail sales tax, but the mechanics of VAT are somewhat different. VAT is a multi-stage tax on the value added of taxable businesses. Each taxable seller is charged VAT on its sales, but receives a tax credit for VAT paid on its intermediate inputs. In virtually all countries, VAT is a destination-based tax: VAT is charged on the full value of goods and services imported from abroad, and no VAT is charged on the sales of exporters, who receive input tax credits for VAT paid on intermediate inputs. Important for our analysis, all imports including of intermediate inputs are typically subject to VAT. Domestic businesses that are VAT-compliant receive credits for VAT paid on imported intermediates while paying tax on sales to final consumers. In contrast, non-compliant firms are not eligible for input tax credits, so that any VAT paid on imported intermediates constitutes a "final tax" that contributes to net revenues received by government.

If all consumer goods and services are taxable at a single rate of VAT on a destination basis ${ }^{11}$ then standard economic theories imply taxes are shifted forward to consumers such that VAT is a consumption tax (Ebrill et al., 2001).$^{12}$ In practice, most countries (especially European countries) levy reduced VAT rates on some commodities such as groceries and home heating. This gives rise to the "policy gap" discussed previously.

Other studies have attempted to estimate country-level VAT compliance gaps using variants of two methodologies known as "bottom up" and "top down" approaches. The bottom up approach uses micro data on taxpayers and transactions (often from tax audits) to estimate direct and indirect measures of tax compliance. A small but growing academic literature explores VAT compliance based on this approach (e.g. Pomeranz, 2015; Gadenne et al., 2018; Almunia et al., 2019). A limitation of these studies is that it may be difficult to generalize non-compliance rates for the aggregate economy (Slemrod, 2018). The top down approach instead uses input-output data and statutory tax rate information to estimate the "theoretical" VAT revenues that would be paid under

\footnotetext{
${ }^{11}$ In a small number of cases, national governments use the term "value added tax" to describe sales or turnover taxes that are not rebated on exports, or that do not allow deduction or exemption for investment purchases. As described below, we exclude these countries from our empirical analysis.

${ }^{12}$ See Benzarti and Carloni (2019) on the economic incidence of real-world VATs.
} 
full compliance, and compares this to revenues actually collected (see Keen (2013)). This method is data-intensive, and has generally been applied only to European and other high-income countries. While both approaches can be useful when the required data is available, they preclude examination of compliance in countries for which the required data or field experiments are not available. This is frequently the case in less-developed countries for which compliance is a major issue.

Our approach is related to the top down approach, but it uses much simpler national accounts data and well-measured trade data to estimate correlations in the data over time, rather than accounting methods for a single time period. Our method is therefore less data-intensive in important respects, permitting us to recover estimates of the compliance gap for countries where input-output data is unavailable, or is considered to be highly unreliable; Again, these are often the countries where concerns about VAT non-compliance are greatest. Moreover, unlike the top down method, our method permits us to attach standard errors to our estimates and perform hypothesis testing on our estimated non-compliance rates.

The specific links we investigate between imports and VAT revenues are directly informative about several policy questions. There is considerable interest in how and why VAT compliance gaps vary among countries and over time [see, e.g., Reckon (2009); Barbone et al. (2013); and Ueda (2017)]. We show that much of these differences are an artifact of the share of imports in consumption. According to our results, year-to-year variation in imports explains about to percent of the within-country variation in revenue performance in aggregate in the data. But this share exceeds 40 percent in Africa, and 20 percent in Asian and Latin American countries ${ }^{13}$ Moreover, some government policies directly impact the share of consumption that is subject to VAT at the border - as for example when countries accede to a common market and relax border controls for trade with partner nations. Our work may therefore be informative about the unintended consequences of single-market treatment of trade for VAT compliance and revenues.

The paper is organized as follows. Section 2 lays out the simple structural model underling our estimation strategy. Section 3 discusses the data and estimation strategy. Section 4 presents results pooled across countries or countries grouped by institutional quality. Section 5 examines heterogeneity in the compliance gap across countries grouped by geography and institutional quality. Because these results in these sections are derived under the assumption that the policy gap is the same on average for domestic and imported consumption, section 6 relaxes the assumption of equal policy gaps for domestically produced and imported goods. It also deals with the special VAT rules applying to trade between member states in the single market of the European Union. We then report estimates of the compliance gap for individual countries, and compare them to existing accounting estimates for EU countries. Section 7 explores correlates of our estimated compliance gaps with measures linked to existing theories of compliance. Section 8 concludes.

\footnotetext{
${ }^{13}$ The reported statistics are $R^{2}$ statistics for the within regression of C-efficiency on the import ratio alone.
} 


\section{Model}

This section constructs a simple, estimable model of VAT revenue performance in the presence of compliance and policy gaps. Initially we consider a single country and time period. There are $G$ commodities, and the statutory VAT rate applying to commodity $g=1, \ldots, G$ is $\tau_{g}{ }^{14}$ We study a destination-based consumption VAT, i.e. one that does not apply to purchases of investment goods, and that is levied on imports, while exempting domestic production that is exported. Thus, domestic producers of commodity $g$ pay tax at rate $\tau_{g}$ on sales $y_{g}$ not destined for export $x_{g}$ or use in investment $i_{g}$, while receiving a credit for taxes paid on purchases of intermediate inputs $n_{g j}$, for each $j=1, \ldots, G$. As well, aggregate imports $m_{g}$ are subject to tax, irrespective of whether they are used in production or final consumption, with taxes on intermediates refunded to tax-compliant firms at the next stage of the chain.

A fraction $\gamma$ of domestic value added escapes taxation due to non-compliance. In contrast, due to enforcement through international border controls, 1oo percent of (measured) imports are subject to VAT. 15 Actual tax revenues are therefore

$$
R=(1-\gamma) \sum_{g}\left[\tau_{g}\left(y_{g}-x_{g}-i_{g}\right)-\sum_{j} \tau_{j} n_{g j}\right]+\sum_{g} \tau_{g} m_{g} .
$$

The material balance identity, equating sources and uses of commodity $g$, implies that

$$
y_{g}-x_{g}-i_{g}=c_{g}+\sum_{j} n_{j g}-m_{g}
$$

Substituting into (1) and collecting terms, actual revenues are simply

$$
R=\sum_{g} \tau_{g}\left[(1-\gamma) c_{g}+\gamma m_{g}\right]
$$

This expresses VAT revenues as a function of vectors of consumption and gross imports (including of intermediates). Observe that, when $\gamma=0, R=\sum \tau_{g} c_{g}$ : with full compliance, a VAT is equivalent to a variable-rate consumption tax. Observe also that, regardless of the compliance rate $\gamma$, taxes levied on intermediate inputs are refunded and do not affect net revenues, except to the extent they are imported and so comprised in $m_{g}$.

It is evident from (2) that VAT revenues depend on policy choices $\tau$ as well as non-compliance

\footnotetext{
${ }^{14}$ By convention, we measure sales at purchaser prices, inclusive of tax. Therefore the standard tax rate is here defined to be the "tax-inclusive rate," levied on the full value of consumption including taxes.

${ }^{15}$ Note that the model does not preclude evasion of VAT on imports that are smuggled into the domestic economy. Instead, we require full VAT compliance for legal imports that are measured in the national accounts. So the assumption of full compliance for imports, while crucial to our approach, is innocuous.
} 
$\gamma$. A common measure of VAT revenue performance is C-efficiency (Ebrill et al., 2001), defined as the ratio of actual revenues to that which would theoretically be collected by applying the standard statutory tax rate $\tau^{S}$ to aggregate final consumption expenditures in the economy. Define aggregate consumption $C=\sum c_{g}$ and imports $M=\sum_{g} m_{g}$. An "ideal" VAT applying the standard tax rate to all consumption would raise revenues $R^{*}=\tau^{S} C$. Using (2), the C-efficiency metric in our model is therefore

$$
E=\frac{R}{R^{*}}=(1-\gamma) \frac{\tau^{D}}{\tau^{S}}+\gamma \frac{\tau^{M}}{\tau^{S}} \frac{M}{C}
$$

where $M / C$, the ratio of aggregate imports to final consumption (henceforth the "import ratio"), and the average effective tax rates on consumption and imports are

$$
\tau^{D}=\sum_{g} \tau_{g}\left(c_{g} / C\right) \quad \tau^{M}=\sum_{g} \tau_{g}\left(m_{g} / M\right) .
$$

These effective tax rates can differ from the standard statutory rate of VAT, $\tau^{S}$, due to policyinduced rate reductions. The ratio $\tau^{D} / \tau^{S}$ of the average effective statutory VAT rate to the standard VAT rate is typically less than one, because of the policy gap.

In an idealized VAT, with no policy gap and full compliance, $\tau^{D}=\tau^{M}=\tau^{S}$ and $\gamma=0$, so that (3) shows that $E=1$. But in actual VATs it is typically the case that $E<1$, due to the combined effect of policy and compliance gaps ${ }^{16}$

Our objective is to use (3) to decompose the percentage revenue loss $1-E$ into the policy gap and the compliance gap. This objective is not new: see for example Keen (2013). But previous efforts at decomposition used accounting methods which require strong assumptions and detailed sectoral data. Our approach instead relies on analysis of variance methods applied to (3), together with our identifying assumption that there is full compliance for measured imports.

\section{Data and estimation}

We observe C-efficiency and import ratios $\left(E_{i t}, M_{i t} / C_{i t}\right)$ for a panel of countries $i=1, \ldots, N$ and years $t=1, \ldots, T$. Equation (3) is an identity that implicitly defines the effective tax rates applying to aggregate imports and domestic consumption in any country and year. To estimate the underlying relationship, we may posit that the effective tax rates reflect average policy gaps on domestic consumption and imports, $\pi_{i}^{D}$ and $\pi_{i}^{M}$, respectively, that are unvarying within countries,

\footnotetext{
${ }^{16}$ As well, $E>1$ is possible, if for example VAT revenues are collected by taxing intermediate inputs in some "VAT-exempt" sectors that do not have a right to claim input tax credits.
} 
plus mean-zero error terms:

$$
\begin{aligned}
& \frac{\tau_{i t}^{D}}{\tau_{i t}^{S}}=\left(1-\pi_{i}^{D}\right)+\epsilon_{i t}^{D} \\
& \frac{\tau_{i t}^{M}}{\tau_{i t}^{S}}=\left(1-\pi_{i}^{M}\right)+\epsilon_{i t}^{M} .
\end{aligned}
$$

Substituting these into equation (3) yields an estimating equation

$$
E_{i t}=a_{i}+b_{i} \frac{M_{i t}}{C_{i t}}+u_{i t}
$$

where

$$
a_{i}=\left(1-\gamma_{i}\right)\left(1-\pi_{i}^{D}\right) \quad \text { and } \quad b_{i}=\gamma_{i}\left(1-\pi_{i}^{M}\right)
$$

are the reduced-form intercept and slope parameters of the model for country $i$, and

$$
u_{i t}=\left(1-\gamma_{i}\right) \epsilon_{i t}^{D}+\gamma_{i} \frac{M_{i t}}{C_{i t}} \epsilon_{i t}^{M}
$$

is a reduced form error term.

Observe that equation (7) suggests that the import ratio is a potentially endogenous regressor in our errors-in-variables setting if innovations to the average effective tax rates are correlated with the share of consumption that is imported. This endogeneity might reflect measurement error, or business cycle effects correlated with average tax rates ${ }^{17}$ To address this, we explore instrumental variables strategies in some specifications and control for potentially confounding variables.

The model allows $\gamma_{i}$ to differ in arbitrary ways among countries, but we lack sufficient time series data to estimate $\gamma_{i}$ non-parametrically for individual countries. Instead, we pool data across groups of countries and allow for heterogeneity in the treatment effect of imports on revenues by estimating the panel data regression

$$
E_{i t}=a_{i}+b\left(\mathbf{w}_{i}\right) \cdot \frac{M_{i t}}{C_{i t}}+x_{i t}{ }^{\prime} \theta+u_{i t} \quad t=1, \ldots, T ; i=1, \ldots, N
$$

where $x_{i t}$ are control variables, $\mathbf{w}_{i}$ are time-invariant characteristics of countries believed to be correlated with tax compliance, and $\theta$ and $b\left(\mathbf{w}_{i}\right)$ are vectors of parameters/functions to be estimated $\sqrt{18}$ Given least squares estimates, we recover estimates of the effect for individual countries

\footnotetext{
${ }^{17}$ For example, our OLS estimates might be biased if imports in the national accounts were adjusted by statistical authorities to capture estimates of smuggled imports that are not subject to VAT. We thank Joel Slemrod for pointing this out.

${ }^{18}$ We recenter control variables $x_{i t}$ by subtracting country means to ensure their inclusion does not affect the estimate of the country fixed effect $a_{i}$, which is relevant to estimating structural gap parameters as discussed below.
} 
from $\hat{b}_{i}=\widehat{b}\left(\mathbf{w}_{i}\right)$.

\subsection{Recovering gap estimates}

While estimates of the slope $b_{i}$ are of independent interest, our ultimate goal is to recover an estimate of the structural compliance gap $\gamma_{i}$, which in turn depends on the latent policy gap parameters $\pi_{i}^{D}$ and $\pi_{i}^{M}$ in equation (6). In general, equation (3) shows that the observed correlation between VAT revenues and imports is consistent with different degrees of non-compliance, depending on the effective tax rate applied to imports. To deal with this, we consider two approaches.

First, if $\pi_{i}^{M}$ is not observed, it is still possible to recover estimates of gap parameters from the model, under the assumption that the effective tax rate applying to imports and domestic value added is the same on average. To see this, set $\pi_{i}^{M}=\pi_{i}^{D}$ in equation (6). Then a consistent estimate of the compliance gap $\hat{\gamma}_{i}$ is

$$
\hat{\gamma}_{i}=\frac{\hat{b}_{i}}{\hat{a}_{i}+\hat{b}_{i}}
$$

where $\left(\hat{a}_{i}, \hat{b}_{i}\right)$ are least-squares estimates of reduced-form intercept and slope 19

The assumption of equal average effective tax rates might be questioned, as domestic industrial policy concerns might lead countries to levy reduced tax rates on commodities that are disproportionately produced domestically rather than imported. In light of this, in our second approach, we hand-collected information on effective tax rates applying to imports for a subset of countries in the sample which allows us to use a more direct approach to validate our estimates of $\gamma_{i}$ which we describe in section 6.1.

The compliance gap $\gamma_{i}$ is the fraction of domestic value added that escapes taxation due to non-compliance. For comparison to other estimates in the literature, however, it is more useful to measure the fraction of aggregate consumption that escapes taxation through non-compliance - this fraction will be lower than the former, because of the additional taxes collected at the border on imports. If we define the revenue lost due to non-compliance alone from equation (3) as

$$
\Delta R_{i}=\gamma_{i} \tau_{i}\left(C_{i}-M_{i}\right)
$$

then the compliance loss as a percentage of total potential revenues is

$$
\gamma_{i}^{*}=\frac{\Delta R_{i}}{\tau_{i} C_{i}}=\left(1-M_{i} / C_{i}\right) \gamma_{i} .
$$

The aggregate compliance gap $\gamma_{i}^{*}$ merely scales down the domestic compliance gap $\gamma_{i}$, multiplying it by one minus the share of imports in domestic consumption.

\footnotetext{
${ }^{19}$ The policy gaps cancel out from numerator and denominator.
} 


\subsection{Data}

Table 1: Summary statistics

\begin{tabular}{lccccc}
\hline & \multicolumn{5}{c}{ (1) } \\
& mean & sd & p10 & p50 & p9o \\
\hline C-efficiency & 0.57 & 0.13 & 0.42 & 0.55 & 0.73 \\
Import ratio & 0.65 & 0.30 & 0.33 & 0.58 & 1.07 \\
Intra-EU import ratio & 0.17 & 0.25 & 0 & 0 & 0.53 \\
EU member & 0.41 & 0.49 & 0 & 0 & 1 \\
Standard VAT rate & 17.7 & 4.95 & 10 & 19 & 23 \\
Rate increase & 0.062 & 0.24 & 0 & 0 & 0 \\
Governance index & 0.73 & 1.11 & -0.92 & 0.79 & 2.21 \\
\hline Observations & 1101 & & & & \\
\hline
\end{tabular}

The data set is a panel of 74 countries observed in the 1991-2016 period. A full list of countries and years covered is presented in the Appendix. Data for annual VAT revenues and statutory tax rates are taken from the Tax Policy Revenue Mobilization Database of the International Monetary Fund, and aggregate consumption and imports from the IMF's World Economic Outlook. The panel is unbalanced, with an average of 16 annual observations per country ${ }^{20}$ The principal data for estimation are summarized in Table 1. The average level of C-efficiency in our data is 0.57; that is, VAT revenues are 57 percent of that which would be generated by an ideal VAT with no policy or compliance gap, given the standard rate; there is considerable variation in C-efficiency across countries and over time. Imports average 65 percent of final consumption in the data, with wide variation; imports exceed 100 percent of consumption in about 15 percent of the sample. About 41 percent of observations in the sample are from member countries of the European Union. As discussed below, VAT is levied somewhat differently on imports among member states of the EU, because of single-market rules. To address this, we obtained data on intra-EU imports from Eurostat for the 1999-2016 period. Intra-EU imports are about 17 percent of consumption on average in the sample, but this reflect zeroes for non-member states: intra-EU imports are 40 percent of consumption on average for observations on member states.

We draw on the World Bank Worldwide Governance Indicators (WGI) to measure country-level institutional characteristics that may be related to tax compliance behaviour (Kaufmann et al., 2009).

\footnotetext{
${ }^{20}$ From the IMF data, we exclude two countries (Colombia and Mongolia) that tax investment goods or exports through the VAT, as these are inconsistent with our model. We exclude as potential outliers observations with imports in excess of 200 percent of consumption, which occur in Luxembourg, Malta after 2008, and Ireland after 2015. Luxembourg in particular does not fit our model of destination-basis VAT, as its abnormally high VAT revenues reflect in part digital service companies headquartered there whose exports are taxed at source under EU rules.
} 
Figure 2: Pooled estimator

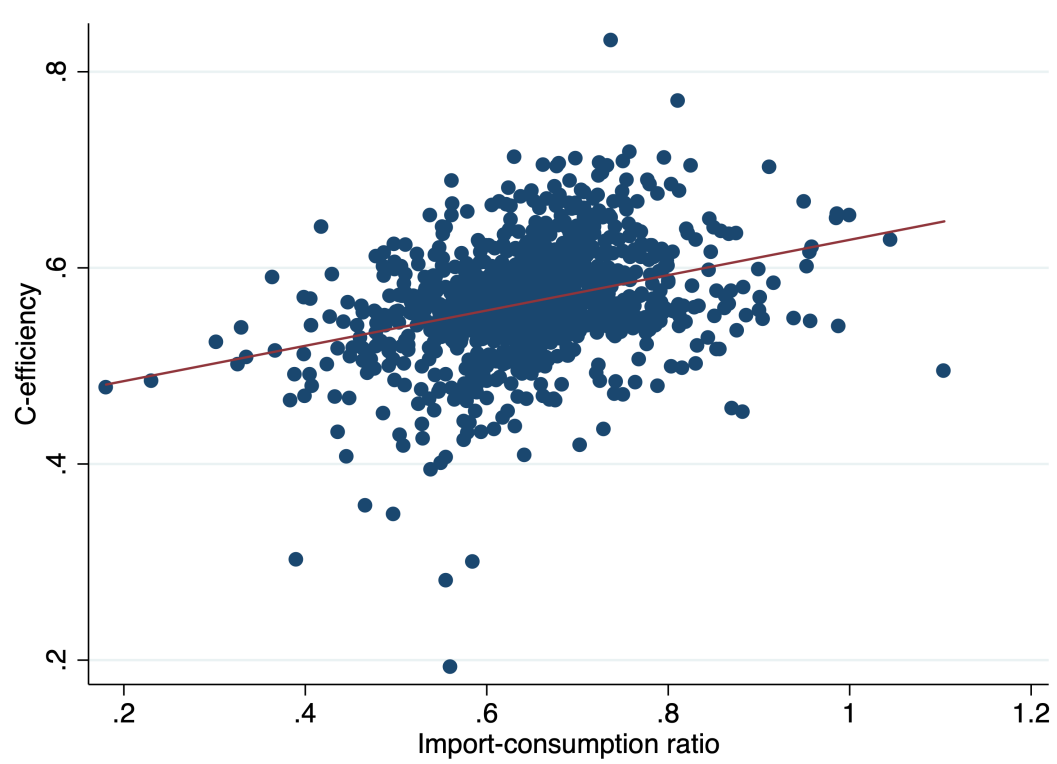

Note: The figure shows C-efficiency for each country and year against the ratio of imports to final consumption. Each dot is a country-year pair demeaned by country and re-centered using the sample mean. The line of best fit has a slope of 0.18 and clustered standard error of 0.04 .

The World Bank data aggregate institutional measures into six indexes that are intended to capture perceptions of different institutional dimensions. We focus on the Control of Corruption indicator, "capturing perceptions of the extent to which public power is exercised for private gain, including both petty and grand forms of corruption, as well as 'capture' of the state by elites and private interests." Index values are standardized to have mean zero in the population of countries and unit standard deviation; in our sample of countries, the mean is higher at 0.73 . Of course, the corruption index is highly correlated with other WGI indexes, which are intended to measure perceptions of other aspects of state and civil society institutions of countries.

\section{Pooled estimates}

We begin by reporting estimates for pooled data specifications, with a single slope parameter $b$ estimated for all countries. Although heterogeneity in tax compliance is likely, this is a useful starting point for our analysis. Preliminary evidence on this relationship can be discerned from Figure 2, which is a scatterplot of our two key variables, C-efficiency and the import ratio. The levels of these variables may be correlated across countries for other reasons that have no causal interpretation. We therefore recenter the data, subtracting country-specific means of the variables and adding means for the global sample. There is evidently a positive relationship between the 
variables within countries: the slope of the line of best fit in Figure 2 is o.180 (s.e. $=0.042$ ). ${ }^{21}$ But this may reflect the effects of other, omitted variables related to the evolution of both VAT revenues and imports. The aggregate evidence from the pooled data also masks considerable heterogeneity in the relationship across countries. To deal with these issues, we turn to regression analysis.

Table 2 reports estimates of $b$ for the pooled sample, using alternatively strategies to control for potential confounders. The first column reports results from the simplest specification, with only country and year fixed effects as controls, so that $b$ is identified from a difference in difference estimate, reflecting changes in import ratios within a country compared to the contemporaneous average of all countries. The estimated $\widehat{b}=0.185($ s.e. $=0.044)$, slightly higher than the specification reported in Figure 2 with only country fixed effects, but essentially the same. Standard errors here and through the paper are robust to arbitrary forms of heteroskedasticity and clustered by country.

The remaining rows of the table report estimates of compliance and policy gaps for this specification. The domestic compliance gap $\hat{\gamma}$, estimated from equation (9), is 0.29 (s.e.=0.062). Standard errors for the gap parameters are estimated using the delta method. Thus our main result from the pooled specification with homogeneous treatment effects is that VAT non-compliance reduces the effective domestic tax base by 29 percent in the average country. This is for the domestic component of the base: if, as we assume, there is perfect compliance for imports, then the aggregate compliance gap is the lower amount estimated from equation (10). For this specification, the estimated aggregate compliance gap is 10.3 percent of revenues. Finally, our approach also allows us to estimate the policy gap, i.e. the fraction of revenues lost due to deliberate departures from uniform taxation at the standard rate, under the assumption that the policy gap is the same on average for domestic and imported consumption. The policy gap for this specification, estimated from equation (6), is 36.9 percent. All these estimates are significantly different from zero.

The second column adds parametric controls. These include the logarithm of the VAT rate, since higher tax rates should be associated with greater incentives for non-compliance ${ }^{22}$ and an indicator variable for years in which the VAT rate was increased, since revenues may lag tax rate increases leading to a temporary fall in C-efficiency. ${ }^{23}$ Also included is the log of aggregate consumption, to capture business cycle effects that may be correlated with both C-efficiency and the import ratio (consumption is in the denominator of both ratios, yield potential for mechanical correlation). Inclusion of these controls should be regarded as a conservative strategy to remove potential sources of endogeneity and ensure stationarity, so that estimates reflect the mechanism of interest.

Comparing columns 1 and 2, the resulting estimate of $b$ is virtually unchanged at 0.186 , as are the implied estimates of the gaps $\gamma, \gamma^{*}$, and $\pi$. On balance this suggests considerable robustness

\footnotetext{
${ }^{21}$ Standard errors are clustered by country.

${ }^{22}$ See e.g. Agha and Haughton (1996) and Barbone et al. (2013).

${ }^{23}$ Robustness tests unreported here show that a corresponding dummy variable for tax rate decreases (which are rare) is near zero and insignificant.
} 
Table 2: Pooled estimates

\begin{tabular}{lcccc}
\hline & $(1)$ & $(2)$ & $(3)$ & $(4)$ \\
& OLS & OLS & IV & IV \\
\hline Import ratio & $0.185^{* * *}$ & $0.186^{* * *}$ & $0.255^{* *}$ & $0.144^{*}$ \\
& $(0.044)$ & $(0.042)$ & $(0.092)$ & $(0.062)$ \\
Log VAT rate & & $-0.130^{*}$ & & $-0.134^{* *}$ \\
& & $(0.050)$ & & $(0.049)$ \\
Rate increase & & -0.011 & & -0.012 \\
& & $(0.008)$ & & $(0.008)$ \\
Log consumption & & $0.040^{* * *}$ & & $0.039^{* * *}$ \\
& & $(0.010)$ & & $(0.010)$ \\
\hline Estimated compliance gap $(\%))$ & & & \\
- Domestic & $29.3^{* * *}$ & $29.6^{* * *}$ & $38.9^{* * *}$ & $23.4^{* *}$ \\
& $(6.2)$ & $(6.0)$ & $(12.2)$ & $(9.3)$ \\
- Aggregate & $10.3^{* *}$ & $10.4^{* *}$ & 13.6 & 8.2 \\
& $(3.7)$ & $(3.6)$ & $(7.2)$ & $(5.5)$ \\
Policy gap & $36.9^{* * *}$ & $36.9^{* * *}$ & $34.4^{* * *}$ & $38.4^{* * *}$ \\
& $(1.5)$ & $(1.5)$ & $(3.3)$ & $(2.2)$ \\
First-stage F & & & 24.2 & 15.4 \\
Hansen's J & & & 3.1 & 0.8 \\
Observations & 1101 & 1101 & 1099 & 1099 \\
\hline
\end{tabular}

Note: The top panel presents reduced form coefficients from estimation of (5). The bottom panel presents structural estimates of domestic compliance gap $\gamma$, aggregate compliance gap $\gamma^{*}$, and policy gap $1-\pi$. Columns (3) and (4) report two-stage least squares estimates, where excluded instruments for the import ratio are bilateral exchange rates with Dollar, Euro, and Yen. All specifications include year and country fixed effects. Standard errors in parentheses, clustered by country.

${ }^{*} p<0.05,{ }^{* *} p<0.01,{ }^{* * *} p<0.001$.

of estimates to controls for potential confounders in OLS specifications. C-efficiency is also significantly negatively related to the stndard statutory tax rate: the estimate implies that a one percent increase in the tax rate leads to a reduction in the tax base of 0.13 percent implying a semi-elasticity of -0.23 .

OLS estimates here are potentially biased, as discussed in Section 3, because of the way time varying effective tax rates may be correlated with the import ratio. In addition, our estimates may be biased may be towards zero, if there is measurement error in the the import ratio due to imperfectly capture of the portion of imports that is subject to border controls. This is possible, given that our import data include imports of services which are not subject to the same scrutiny and which in any case are not liable for VAT in the tax systems of some countries. To deal with this potential measurement error in the import ratio, we explore two-stage least squares estimates. We 
instrument for the import ratio with nominal exchange rates: for each country and year in the data, we measure the annual average of its bilateral exchange rate with major currencies (the US Dollar, Euro, and Yen). This picks up shocks to the import ratio that are driven by changes in nominal valuations.24

In columns 3 and 4 of Table 2, we report 2SLS estimates using these instruments for the same specifications as for OLS in columns 1 and 2. First stage instruments have considerable explanatory power as reported in the Table. The estimated 2SLS coefficients are similar to OLS estimates. In column 3, without parametric controls, the 2SLS estimate is somewhat larger, reflecting the potential importance of measurement error. On the other hand, when parametric controls are included, the two estimates are essentially the same. For this reason, and because our subsequent results relate to smaller groups of countries for which small-sample properties of the 2SLS estimator are unattractive, we report only OLS results in subsequent tables.

\subsection{Discussion}

Are these gaps large or small? The aggregate compliance gap of 10 percent is fairly small and, as we discuss further below, similar to existing estimates of VAT non-compliance that are available for some high-income countries. On the other hand, the difference between the aggregate and domestic compliance gaps is striking, and it points to the import role of international trade and border controls in enforcing VAT payments. As well, the heterogeneity in estimated compliance gaps among countries, to which we turn next, shows that non-compliance is a more serious problem in some countries than in others. Finally, the estimated policy gap of 37 percent is in line with expectations. Existing estimates of the policy gap for European countries are somewhat higher, at 30-45 percent [Keen (2013)]. However, countries that introduced the tax more recently generally have "modern VATs," with broader bases and more uniform application of the standard rate (Smart. 2012).

\section{Heterogeneity across countries}

One of the objectives of this study is to compare tax compliance across countries. VAT revenue performance as measured by C-efficiency varies among regions of the world, and it is known to

\footnotetext{
${ }^{24}$ We are agnostic as to whether the first stage coefficient should be positive or negative as this will depend where on the "J-curve" the country lies. If prices are more responsive than quantities, as can happen in the short run, a depreciation of the domestic currency will result in a lower value of imports. However, at longer horizons, an exchange rate depreciation tends to drive the value of imports higher as a percentage of consumption. Also, it is important to note that this strategy can address endogeneity coming from omitted variables that also drive average tax rates. However, it will not address the possibility that goods that are imported tend to face systematically higher or lower VAT rates; in this situation, the exclusion restriction can fail. We address this possibility in section 6
} 
Table 3: Estimates by region

\begin{tabular}{|c|c|c|c|c|c|c|c|}
\hline & $\begin{array}{c}(1) \\
\text { Africa }\end{array}$ & $\begin{array}{c}(2) \\
\text { Asia }\end{array}$ & $\begin{array}{c}(3) \\
\mathrm{LAC}\end{array}$ & $\begin{array}{l}\text { (4) } \\
\text { E. Europe }\end{array}$ & $\begin{array}{c}\text { (5) } \\
\text { S. Europe }\end{array}$ & $\begin{array}{c}(6) \\
\text { N. Europe }\end{array}$ & $\begin{array}{c}(7) \\
\text { Other OECD }\end{array}$ \\
\hline Import ratio & $\begin{array}{l}0.490^{*} \\
(0.218)\end{array}$ & $\begin{array}{l}0.590^{* *} \\
(0.129)\end{array}$ & $\begin{array}{l}0.442^{*} \\
(0.179)\end{array}$ & $\begin{array}{c}0.226^{* * *} \\
(0.045)\end{array}$ & $\begin{array}{c}0.143 \\
(0.082)\end{array}$ & $\begin{array}{c}0.024 \\
(0.059)\end{array}$ & $\begin{array}{l}-0.030 \\
(0.118)\end{array}$ \\
\hline \multicolumn{8}{|c|}{ Estimated compliance gap (\%): } \\
\hline - Domestic & $\begin{array}{l}72.2^{* *} \\
(24.8)\end{array}$ & $\begin{array}{c}69.8^{* * *} \\
(11.4)\end{array}$ & $\begin{array}{c}55.6^{* * *} \\
(16.2)\end{array}$ & $\begin{array}{c}36.6^{* * *} \\
(6.7)\end{array}$ & $\begin{array}{l}25.7^{*} \\
(13.1)\end{array}$ & $\begin{array}{c}4.2 \\
(10.3)\end{array}$ & $\begin{array}{c}-5.1 \\
(20.5)\end{array}$ \\
\hline - Aggregate & $\begin{array}{c}23 \\
(14.0)\end{array}$ & $\begin{array}{c}25 \cdot 4^{* * *} \\
(6.9)\end{array}$ & $\begin{array}{l}28.1^{* *} \\
(11.5)\end{array}$ & $\begin{array}{l}7 \cdot 5^{* *} \\
(3.1)\end{array}$ & $\begin{array}{l}10.8 \\
(8.5)\end{array}$ & $\begin{array}{c}1.4 \\
(5.9)\end{array}$ & $\begin{array}{c}-3.2 \\
(16.3)\end{array}$ \\
\hline Policy gap & $\begin{array}{c}32.1^{* * *} \\
(6.9)\end{array}$ & $\begin{array}{c}15 \cdot 5^{* * *} \\
(4.7)\end{array}$ & $\begin{array}{c}20.4^{* *} \\
(9.0)\end{array}$ & $\begin{array}{c}38.1^{* * *} \\
(0.9)\end{array}$ & $\begin{array}{c}44.2^{* * *} \\
(3.5)\end{array}$ & $\begin{array}{c}43 \cdot 5^{* * *} \\
(1.9)\end{array}$ & $\begin{array}{c}40.7^{* * *} \\
(7 \cdot 4)\end{array}$ \\
\hline Observations & 69 & 100 & 106 & 309 & 131 & 285 & 101 \\
\hline
\end{tabular}

Note: Estimates for regional subsamples corresponding to column (2) of Table 2 All specifications also include controls for $\log$ consumption, $\log$ of the standard VAT rate, and a dummy variable for years of rate increases. For further details, see notes to Table 2. All specifications include year and country fixed effects. Standard errors in parentheses, clustered by country.

${ }^{*} p<0.05,{ }^{* *} p<0.01,{ }^{* * *} p<0.001$.

be somewhat higher in east Asia, and the "Other OECD" countries of Australia, New Zealand, Canada, and Japan, and lower in Africa and South Europe. ${ }^{25}$ But this may reflect differences in the policy gap rather than compliance.

Table 3 shows how estimates of $b$ and structural gaps vary among regions. Each column of the table reports key estimates from a separate regression on a subsample of observations in a particular region. All specifications include country and year effects plus the same parametric controls as in column 2 of Table 2, although these are unreported in the table for the sake of brevity. The estimated reduced form slope parameters are large and highly statistically significant in the regions of Africa, Asia, Latin America, and Eastern Europe; somewhat smaller and insignificant for Southern Europe; and a precisely estimated zero for Northern Europe and the Other OECD countries. The implied domestic compliance gaps are all very large and highly statistically significant in the former four regions, ranging from 72 percent of domestic tax base lost in Africa to 36 percent in Eastern Europe. ${ }^{26}$ This is consistent with the notion that compliance differs systematically among countries and regions of the world.

An alternative interpretation of these results by region is as an analysis of variance, measuring

\footnotetext{
${ }^{25}$ In our data, average C-efficiency is 72 percent in East Asia, 61 percent in Other OECD countries, 52 percent in Africa, and 50 percent in South Europe, compared to an unweighted average of 57 percent in our full sample.

${ }^{26}$ On the other hand, estimated policy gaps are smaller in these regions than in Europe, and smaller in Eastern Europe than for the "Old VATs" of Northern and Southern Europe, which where we estimate policy gaps around 40 percent, very similar to the accounting estimates reported in Keen (2013)). In this sense at least, the typical IMF advice to countries newly adopting VAT to establish a broad tax base with uniform rates appears to have been working.
} 
Table 4: Estimates by quintiles of institutional quality

\begin{tabular}{lccccc}
\hline & $(1)$ & $(2)$ & $(3)$ & $(4)$ & $(5)$ \\
& Lowest & $\mathrm{Q}_{2}$ & $\mathrm{Q}_{3}$ & $\mathrm{Q}_{4}$ & Highest \\
\hline Import ratio & $0.494^{* * *}$ & $0.244^{*}$ & $0.176^{* * *}$ & 0.018 & 0.018 \\
& $(\mathrm{o} .115)$ & $(0.092)$ & $(0.041)$ & $(0.086)$ & $(0.073)$ \\
\hline \multicolumn{7}{l}{ Estimated compliance gap $(\%):$} & & & & \\
- Domestic & $63.9^{* * *}$ & $38.8^{*}$ & $28.7^{* * *}$ & 3.2 & 3.1 \\
& $(10.8)$ & $(13.4)$ & $(6.1)$ & $(15.3)$ & $(12.4)$ \\
- Aggregate & $27.8^{* * *}$ & 8.1 & $7.8^{* *}$ & 1.4 & 1.3 \\
& $(7.1)$ & $(6.1)$ & $(3.2)$ & $(10.0)$ & $(8.0)$ \\
Policy gap & $22.7^{* * *}$ & $37.1^{* * *}$ & $38.6^{* * *}$ & $44.2^{* * *}$ & $41.7^{* * *}$ \\
& $(5.0)$ & $(2.0)$ & $(1.1)$ & $(3.7)$ & $(3.0)$ \\
Observations & 233 & 206 & 235 & 213 & 214 \\
\hline
\end{tabular}

Note: Estimates for quintiles of the WGI index for Control of Corruption. All specifications also include controls for $\log$ consumption, log of the standard VAT rate, and a dummy variable for years of rate increases. For further details, see notes to Table 2 All specifications include year and country fixed effects. Standard errors in parentheses, clustered by country.

${ }^{*} p<0.05,{ }^{* *} p<0.01,{ }^{* * *} p<0.001$.

the extent to which variation in VAT revenue performance within countries over time are explained simply by variation in the import ratio. This is of special relevance to those interested in explaining cyclical and structural shifts in VAT compliance in the data. The explanatory power of the import ratio is small for some countries but large for others: the within-country $R^{2}$ statistic (not reported) when regressing C-efficiency on the import ratio alone ranges from near zero in Northern Europe (0.03) and the Other OECD region (0.02), to 20 percent in Eastern Europe and 40 percent in Africa.

In Table 4, we take the same approach to examining the effects of institutional quality. We divide the data into quintile groups of the World Bank Governance Index for the Control of Corruption in the year 2000, and we estimate the pooled model separately for each quintile of countries. Again we report the key estimates for each subsample, and suppress coefficients on control variables. The results show a consistent monotone pattern, with $b$ highest in the bottom quintile and progressively falling across quintiles of increasing higher perceived quality of institutions. Here, the estimated domestic compliance gap ranges from 64 percent in the bottom quintile to 29 percent in the middle quintile, and a fairly precisely estimated zero in the top two quintiles.

All this suggests that our results reflect how institutions affect tax compliance, and that there are large differences in VAT compliance at different levels of institutional quality. But our results do not suggest any particular causal mechanism through which state and civil society institutions affect tax compliance. Our index of institutional quality is correlated with many other characteristics of countries in the sample, including levels of economic development as measured for example by 
GDP per capita. Note as well that tax non-compliance need not mean tax evasion: the high noncompliance in the bottom quintile may reflect in part the large proportion of value added in those countries which accrues to small and informal sector firms, which are typically exempted from VAT for reasons of practicality. Instead, the governance index is used here merely as a plausible way to split the sample into groups of similar countries that are apt to exhibit similar levels of tax compliance due to a variety of factors. That being said, institutions matter to tax compliance.

\section{Extensions}

Our estimates thus far are derived under the assumption that the policy gap is the same on average for domestic and imported consumption. In this section, we relax this assumption, and additionally we address the special VAT rules applying to trade between member states in the single market of the European Union. We then report compliance gap estimates for individual countries and compare them to existing accounting estimates for EU countries.

\subsection{Import VAT rates}

Our estimates of compliance and policy gaps were derived under the assumption that the policy gap is the same on average for domestic and imported value added. This assumption of equal average effective tax rates might be questioned, as domestic industrial policy concerns might lead countries to levy reduced tax rates on commodities that are disproportionately produced domestically rather than imported. We therefore sought additional information on effective import VAT rates in order to validate this approach. We hand-collected information on total VAT revenues collected by customs authorities (as opposed to domestic tax agencies). This information is variously reported as "Customs VAT" or "Import VAT" in public accounts documents of various national governments. We were able to obtain these revenue amounts collected in recent years for 33 of the 74 countries in our sample $\sqrt{27}$ These countries and their import VAT rates are listed in the Appendix. To arrive at the effective VAT rate applying to imports, we divided revenue by the value of total imports of goods to the country as recorded in the WIOD database as constructed by Timmer et al. (2012) or, in the case of European Union member states, total imports of goods to the country from outside the European Union, as measured by Eurostat. The value of imports in the denominator of these calculations excludes services, since VAT on services is not collected by customs authorities.

\footnotetext{
27The data were obtained from annual reports of customs agencies, revenue administration authorities, or finance ministries of national governments in 28 cases, and from other national or international organizations in the remaining 5 cases. For example, the data for the UK are from the Monthly VAT Bulletin at https://www.gov.uk/government/statistics/value-added-tax-vat-bulletin.
} 
Dividing this calculated effective import VAT rate in turn by the country's standard statutory VAT rate, we arrive at an estimate of $1-\pi_{i}^{M}$. When $\pi_{i}^{M}$ is observed, $\gamma_{i}$ can be estimated directly by regressing C-efficiency on the scaled import ratio:

$$
E_{i t}=a_{i}+\gamma_{i}\left(1-\pi_{i}^{M}\right) \frac{M_{i t}}{C_{i t}}+u_{i t}
$$

where $\left(1-\pi_{i}^{M}\right) M_{i t} / C_{i t}$ are now data. The countries for which we have obtained estimates of $\pi_{i}^{M}$ are a selected sample, so that results of this approach may not be directly comparable to the foregoing ones, in the presence of treatment heterogeneity among countries. Indeed, countries are somewhat different in terms of the means of the covariates. Countries in this subsample are somewhat less open than in the main sample (mean import ratio of 0.58 , compared to 0.72 for the excluded countries) and, perhaps unsurprisingly, scores higher in terms of the WGI metric of institutional quality ( $\bar{w}_{i}=1.10$ compared to 0.33 for the excluded countries), and have a higher level of economic development, with approximately twice the per capita GDP of the excluded countries. On the other hand, there is no significant difference in the mean value of C-efficiency or standard VAT rate between the two groups.

Initial inspection of the estimated import VAT rates suggests that there is little difference between to the two approaches to estimating gaps. On average, the import VAT rate is 75 percent of the standard VAT rate in the selected sample. In Table 2 (column 2) above, based on the uniform VAT rate assumption, we estimated an average policy gap that implies the average effective domestic VAT rate is 67 percent of the standard rate. So, consistent with expectations, there is somewhat greater taxation of imported than domestic value added in the average country, but the difference is small.

To examine the importance of the equal-rates assumption in the presence of these differences, we present in Table 5 two sets of estimates of the domestic compliance gap for the subsample of countries with Import VAT rates. In Panel A, we re-estimate equation (5) using the same control variables as before but using this selected sample. The average estimated compliance gap is somewhat larger, at 31.5 percent of revenues, compared to the 29 percent reported above for the full sample. Gap estimates are larger for several quintiles of institutional quality than the corresponding estimates reported in Table 4, although the estimates are rarely statistically significant now partially due to the smaller sample size.

In Panel B, we report the estimates of the domestic compliance gap based on equation (11) using the estimated effective import VAT rates. The two sets of estimates are in fact remarkably similar. The average gap (column 1) in Panel B is 5.6 percentage points higher than in Panel A. Again, heterogeneity across countries is important here, since many countries have estimated compliance gaps near zero in any case. But the differences in the estimates across quintiles of institutional 
Table 5: Estimates of domestic compliance gap using estimated Import VAT rates

\begin{tabular}{lcccccc}
\hline & All & Lowest & $\mathrm{Q}_{2}$ & $\mathrm{Q}_{3}$ & $\mathrm{Q}_{4}$ & Highest \\
\hline \hline A. Base specification: & & & & & & \\
Domestic compliance gap & $31.5^{*}$ & $72.1^{* * *}$ & 38.4 & 51.1 & -1.7 & 11.7 \\
& $(10.7)$ & $(12.0)$ & $(41.6)$ & $(38.3)$ & $(16.7)$ & $(11.5)$ \\
Observations & 553 & 116 & 52 & 52 & 141 & 192 \\
\hline B. Imports scaled by import VAT rates: & & & & \\
Domestic compliance gap & $37.1^{* * *}$ & $83.2^{* * *}$ & 39 & 42.7 & 17.5 & 9.5 \\
Observations & $(10.7)$ & $(19.3)$ & $(46.2)$ & $(58.0)$ & $(11.1)$ & $(8.3)$ \\
\hline \hline
\end{tabular}

Note: Panel A repeats the regressions of Table 4 by quintiles of institutional quality, for the subsample of 33 countries for which Import VAT rates are available. Panel B reports alternative compliance gap estimates based on (11). See the text for further details. All specifications include year and country fixed effects. Standard errors in parentheses, clustered by country. ${ }^{*} p<0.05,{ }^{* *} p<0.01,{ }^{* * *} p<0.001$.

quality are small as well.

In all, these results give a reassuring sense that compliance gaps can be estimated from revenueimport correlations, even in the absence of detailed information on the effective tax rate applying to imports.

\subsection{Compliance in the European single market}

Our approach to estimating compliance is based on the assumption that all imports are subject to VAT, with VAT on imported intermediate inputs being subsequently refunded to businesses that are VAT-compliant, and intermediate VAT on non-compliant businesses retained as a final tax. This assumption is reasonable in most countries, and it is true in EU countries for imports from non-member states.

For trade between EU member states, the advent of the European single market and the associated abolition of internal border controls has led to a different system for taxing business-tobusiness transactions. Under this "reverse charge" system, the purchaser does not pay VAT on imports from suppliers in other member states, and does not receive an input tax credit for imports. Instead, the value of imports is treated as part of the purchaser's taxable value added, which is subject to tax domestically when final outputs are sold.

When there is full compliance, this makes no difference to anyone's VAT liability. There is some risk of non-compliance on imports, because no tax is collected at the border. But tax authorities in member states do have mechanisms for tracking sales between registered businesses in different 
member states, and clearly they believe they can trace these to final sales and ensure compliance. ${ }^{28}$ Nevertheless, the advent of the reverse charge system has been controversial among VAT specialists, many of whom believe that "breaking the VAT chain" in this way may lead to problems of tax evasion (Pomeranz, 2015). In this sense, the development of the single market in Europe, while reducing transactions costs for intra-community trade, may have had inadvertent costs through reductions in VAT compliance.

This proposition is testable with our approach. To do so, consider an extension of the model of Section 2. Suppose now that an EU country imports $M_{0}$ from third countries that are subject to border controls, ensuring full VAT compliance as before, while the reverse charge mechanism is applied to imports $M_{1}$ from other member states, and a fraction $\lambda$ of such imports escape the VAT net, leading to non-compliance at the same rate $\gamma$ as for domestic value added. ${ }^{29}$ Then, analogous to equation (3), VAT revenues are 30

$$
R=(1-\gamma) \tau\left(C-M_{0}-M_{1}\right)+\tau\left(M_{0}+(1-\lambda \gamma) M_{1}\right)
$$

Collecting terms, dividing by potential VAT revenues $\tau_{S} C$ as before, and adding country and time subscripts our estimating equation for C-efficiency for a given country group is now

$$
E_{i t}=a+b \frac{M_{i t}}{C_{i t}}-b_{1} \frac{M_{1 i t}}{C_{i t}}+\epsilon_{i t}^{\prime}
$$

where $M_{i t} / C_{i t}=\left(M_{0, i t}+M_{1, i t}\right) / C_{i t}$ is the aggregate import ratio as before, $M_{1, i t} / C_{i t}$ is the import ratio for intra-EU-community imports to which the reverse charge mechanism applies, $b$ has the same interpretation as before, given in (4), $b_{1}=\lambda \gamma(1-\pi)$ is the incremental effect of intra-EU imports on C-efficiency, and $\epsilon_{i t}^{\prime}$ is a reduced form error term. Thus $b_{1}$ is a measure of the effectiveness of the reverse charge mechanism, relative to the formal border controls that apply to non-EU imports. We then test the null hypothesis $H_{0}: b_{1}=0$. In countries with a domestic non-compliance problem $(\gamma>0)$, we are thereby testing the hypothesis that $\lambda=0$, i.e. that imports between EU countries are taxed in the same way as non-EU imports, so that the reverse charge mechanism works.

To estimate equation (13), we obtained data from Eurostat on the value of imports of goods from EU countries 31 available or the $1999-2016$ period 32 In the regression, this variable is multiplied by a dummy variable for years in which each the importing is a member of the EU, so that the

\footnotetext{
${ }^{28}$ For a more detailed discussion of these issues, see e.g. van Brederode and Gendron (2013).

${ }^{29}$ In terms of previous notation, $M=M_{0}+M_{1}$.

${ }^{30}$ Here for simplicity, we assume that the domestic and import effective tax rates are equal.

${ }^{31}$ We exclude intra-EU imports of services, which are mainly taxed in the origin country, rather than in the destination country through the reverse charge mechanism.

${ }^{32}$ As EU membership changes, so do the countries that comprise this group.
} 
Figure 3: Institutional quality in the European Union

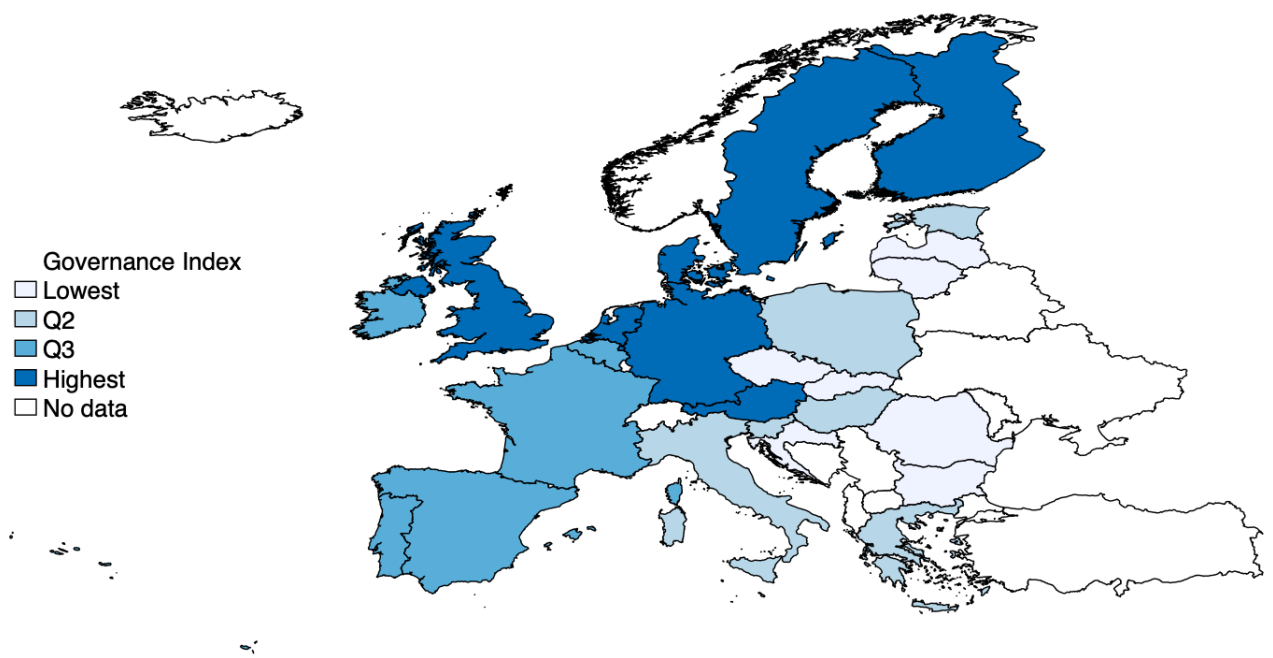

reverse charge system was in operation for intra-EU imports 33 We therefore also include a dummy variable for EU membership years, thereby estimating the direct effect of EU membership on VAT revenues as well. Based on equations (12) and (13), we expect that the effect of the reverse charge mechanism on revenue should confined to countries where domestic tax compliance problems are large. We therefore estimate equation (13) separately for four quartiles of the institutional quality metric for among the 27 member countries in our sample, which are depicted in the map of Figure $33^{34}$ Observe that the quartile groups constitute a nearly contiguous geographic partition, with the highest quartile located in Northern Europe, the second-highest in Western Europe, and the remainder in Southern and Eastern Europe.

Results are reported in Table 6. Estimates of $b$ for total imports shows the same decreasing pattern as reported earlier for the global sample of countries, with significant positive effects in the bottom half of the distribution, but not in the top half. The effect of imports from within the EU is small and negative with point estimate of -0.141 but indistinguishable from zero for countries in the lowest quartile of institutional quality. Thus the estimates provide modest evidence that imports from other EU countries reduce compliance in some countries, so that EU accession has decreased VAT revenues there, although we cannot reject no effect at conventional significance levels. Based on the point estimates, we estimated the aggregate compliance gap in each quartile, adjusting the formula in equation $(10)$ for the estimated proportion of revenue lost due to non-compliance with the reverse charge mechanism. These gap estimates are reported in the bottom panel of the

\footnotetext{
${ }^{33}$ The composition of exporters in $M_{1 i t}$ changes as countries enter the EU. The dummy variable simply turns on when the destination country is also an EU member.

34These quartiles are based on the member countries, not the global sample, to tease out heterogeneity in this group. If the quartiles were based on the global sample most EU countries would be in the top quartile generating little variation.
} 
Table 6: Estimates for EU single market countries

\begin{tabular}{lcccc}
\hline & $(1)$ & $(2)$ & $(3)$ & $(4)$ \\
& Lowest & $\mathrm{Q}_{2}$ & $\mathrm{Q}_{3}$ & Highest \\
\hline Total import ratio & $0.267^{*}$ & $0.200^{* *}$ & -0.016 & 0.075 \\
& $(0.115)$ & $(0.047)$ & $(0.100)$ & $(0.196)$ \\
Intra-EU import ratio & -0.141 & 0.022 & 0.061 & 0.056 \\
& $(0.175)$ & $(0.031)$ & $(0.046)$ & $(0.170)$ \\
EU member & 0.068 & 0.028 & 0.043 & \\
& $(0.079)$ & $(0.016)$ & $(0.023)$ & \\
\hline Observations & 145 & 140 & 130 & 158 \\
Estimated compliance gap $(\%):$ & & & \\
- Domestic & $39.9^{*}$ & $36.0^{* * *}$ & -3.1 & 13.3 \\
& $(14.9)$ & $(7.5)$ & $(19.5)$ & $(32.4)$ \\
- Aggregate & 15.1 & 6.3 & -4.8 & 2.3 \\
& $(11.1)$ & $(3.4)$ & $(8.3)$ & $(22.4)$ \\
Policy gap & $33.1^{* * *}$ & $44.4^{* * *}$ & $48.2^{* * *}$ & $43.5^{* * *}$ \\
& $(4.3)$ & $(1.6)$ & $(3.3)$ & $(11.0)$ \\
\hline
\end{tabular}

Note: The top panel presents reduced form estimates of 13 for quartiles of the WGI index for Control of Corruption within the EU. The bottom panel presents structural estimates of domestic compliance gap $\gamma$, aggregate compliance gap $\gamma^{*}$, and policy gap $1-\pi$. All specifications include year and country fixed effects. Standard errors in parentheses, clustered by country. ${ }^{*} p<0.05,{ }^{* *} p<0.01,{ }^{* * *} p<0.001$.

table. The aggregate compliance gap in the bottom quartile is 15 percent, reflecting relatively high domestic non-compliance, and the relatively low efficacy of the reverse charge mechanism there. The aggregate compliance gap is small in other member states, at least by international standards. Observe that revenues foregone due to the policy gap are far larger than the compliance gap, consistent with the results in Keen (2013) based on accounting methods. 35

\subsection{Country-level estimates}

Our preceding results indicate substantial VAT revenue losses due to non-compliance, especially among countries with low state capacity, as proxied by the WGI index. Those estimates were for groups of countries defined by region or institutional quality, but estimates of compliance and policy gaps for specific countries are of independent interest. Our panels are too short to estimate $\gamma_{i}$ efficiently country-by-country, so that it remains important to estimate marginal effects either

\footnotetext{
${ }^{35}$ Of course, this should not be interpreted as a statement about the welfare effects of the policy gap. Selective rate reductions create both winners and losers in the domestic economy andso have ambiguous welfare impacts. In contrast, revenue losses due to the compliance gap have a less ambiguously negative impact on welfare (Emran and Stiglitz, 2005.
} 
Figure 4: Estimated compliance gaps and institutional quality

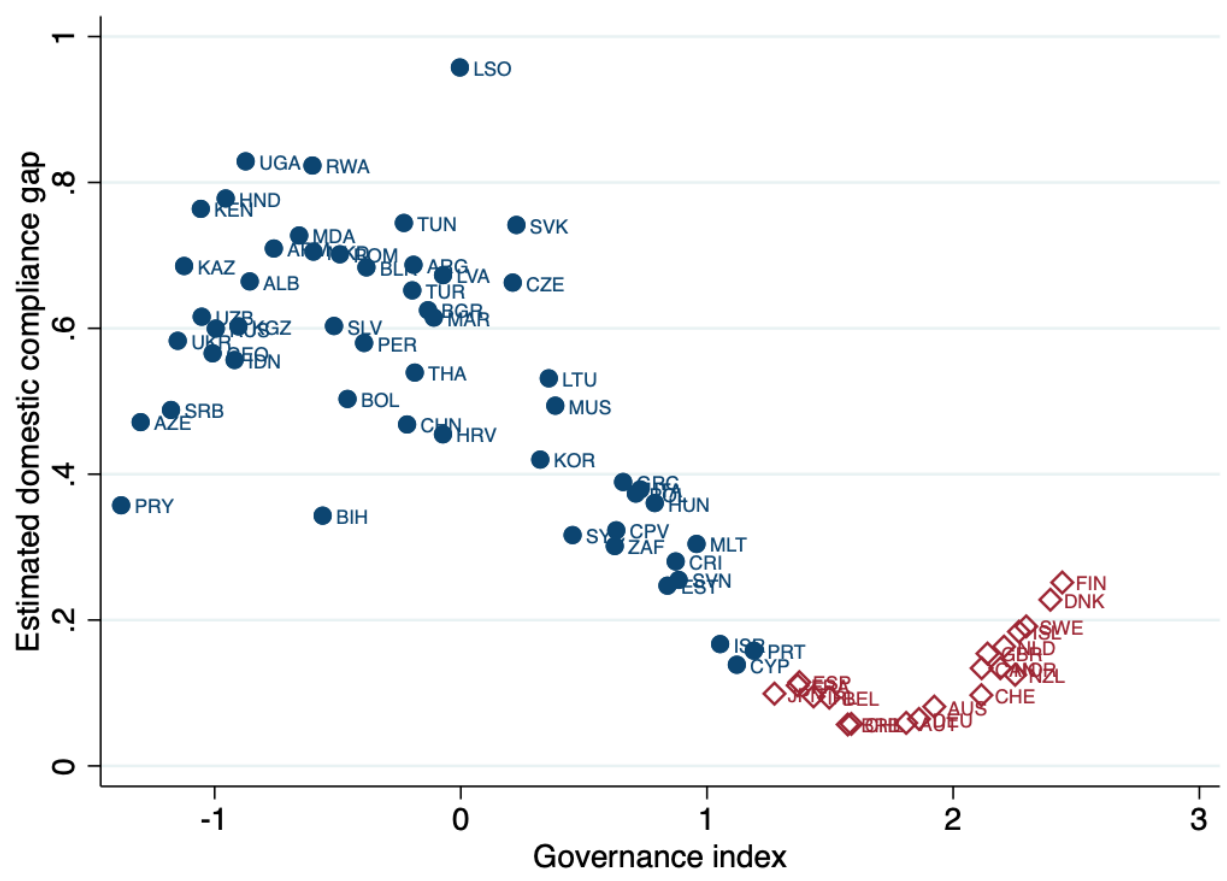

Note: The figure plots the domestic compliance gap $\hat{\gamma}_{i}$ estimated from (14)-15 against the control of corruption index $w_{i}$. Estimates marked with a diamond symbol are insignificantly different from zero $(p=0.05)$.

by group or as a function of characteristics. The foregoing analysis suggests that the Control of Corruption index $w_{i}$ is a good proxy for heterogeneity in VAT compliance. We therefore estimate a saturated parametric model extending equation (13):

$$
E_{i t}=a_{i}+b\left(w_{i}\right) \frac{M_{i t}}{C_{i t}}+b_{1}\left(w_{i}\right) D_{i t}^{E U} \frac{M_{1 i t}}{C_{i t}}+x_{i t}^{\prime} \theta+u_{i t} .
$$

Here, $b\left(w_{i}\right)$ is a fourth-order polynomial in the governance index $w_{i}, b_{1}\left(w_{i}\right)$ is a fourth-order polynomial for EU countries-where the range of $w_{i}$ is much smaller than for the global sample-and $D_{i t}^{E U}=1$ for years that $i$ is in the European Union, capturing the special VAT system of EU countries in the same way as (13). We employ the same control variables as in previous specifications, as well as region-by-year fixed effects for the seven global regions defined in Table 3. We then estimate the domestic compliance gap from the estimated marginal effects of aggregate import ratio, analogous to the linear model estimated above:

$$
\hat{\gamma}_{i}=\frac{\widehat{b}\left(w_{i}\right)}{\hat{a}_{i}+\widehat{b}\left(w_{i}\right)}
$$

Standard errors are computed with the delta method. 
Figure 5: Estimated and accounting gaps for EU countries

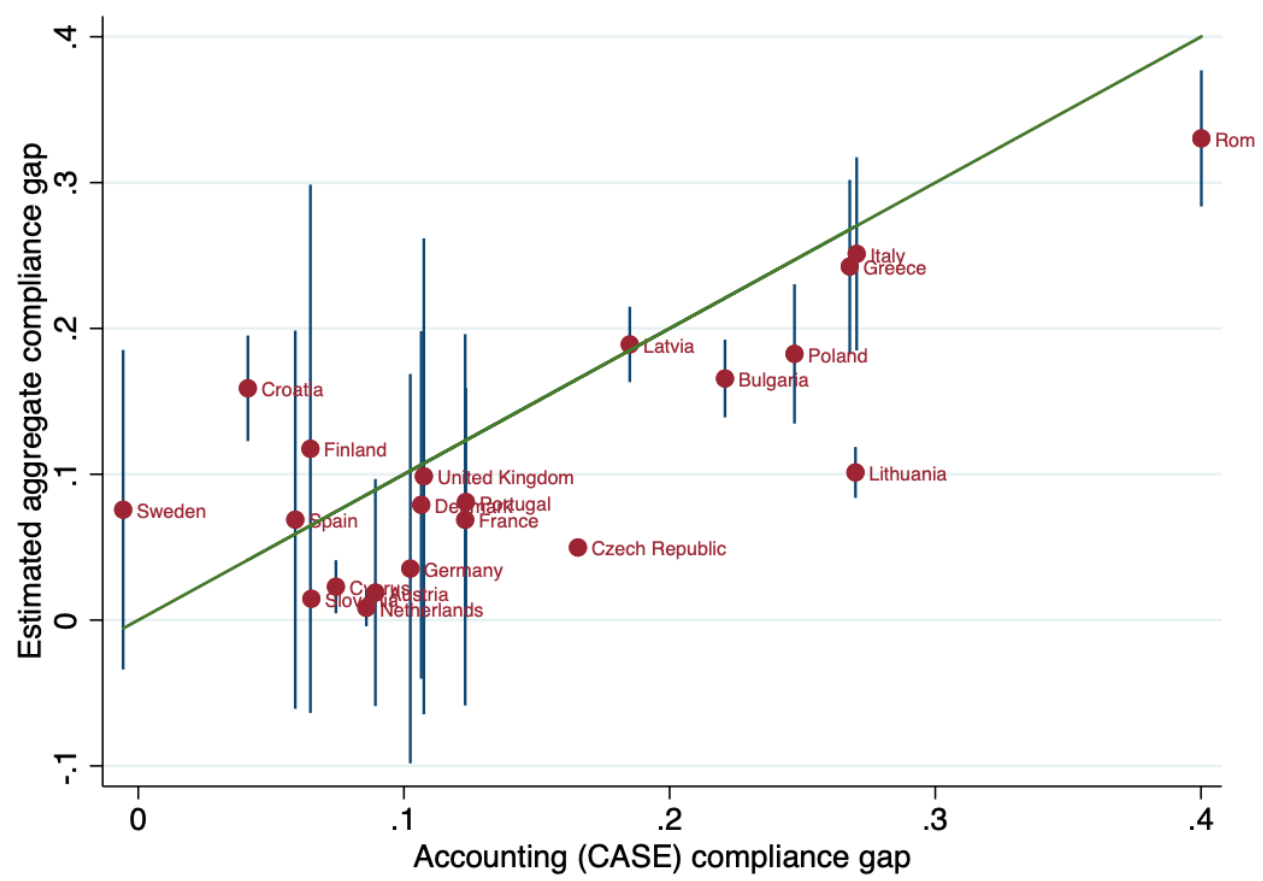

Note: The figure plots accounting estimates of compliance gaps from Barbone et al. (2013) against $\hat{\gamma}_{i}$ from Figure 4, for the 21 countries in common between the two samples. Vertical lines represent 95 percent confidence intervals.

Figure 4 graphs the domestic compliance gaps estimated from this approach $\sqrt{36}$ Hollow dots represent estimates that are not distinguishable from zero whereas filled dots represent estimates where we can reject the null of zero. The estimated compliance gap is broadly decreasing in institutional quality, as expected. There is some evidence of mild "overfit" on the boundaries of the interval of observed $w_{i}$, which is common with higher-order polynomial regressions. The estimated gaps at the upper boundary are not significantly different from zero. The patterns of individual estimates observed in the figure help to elucidate the competing effects of geography and institutions. The highest estimated gaps-in excess of 80 percent of domestic value addedare in African countries, even though these do not have the lowest values of the governance index. Somewhat lower gaps but still high are observed in a number of Asian and Eastern Europe countries for example.

Figure 5 shows estimated compliance gaps from the specification with controls for EU countries. This gives a sense of if our measures line up with external measures when the latter are available, and speaks to whether our measures might be useful when they are not. For these countries, accounting estimates of the compliance gap are available using the top down method from Barbone et al. (2013), and subsequent updates by the European Commission. In this case, we report aggre-

\footnotetext{
${ }^{36}$ For legibility, the figure excludes the estimate for Republic of Congo, which is 250 percent.
} 
gate compliance gaps that adjust for the higher compliance rate for imports, rather than domestic compliance gaps, since that is what is reported in the previous literature 37 The resulting estimates are therefore considerably smaller. The two sets of estimates are graphed against each other in Figure 5 , together with vertical bars indicating 95 percent confidence intervals around our estimated gaps. Compared to the accounting measure, our estimates are broadly similar. Gaps are largest in the newly acceding countries of Eastern Europe, as well as in Italy and Greece. Compliance gaps are less than ten percent and insignificantly different from zero in northern and western European countries. Thus, unlike other regions of the world, losses in potential VAT revenues reflect the policy gap far more than the compliance gap in most EU countries.

\section{Compliance and institutions: An exploratory analysis}

The country-level estimates of Section 6.3 suggest a relationship between perceived corruption and VAT compliance at the national level. Cross-sectional patterns depicted in Figure 4 cannot be taken as evidence of any causal link between compliance and institutional quality among countries, as many other observable and unobservable factors correlated with corruption perceptions may also explain differences in compliance gaps among countries. Moreover, as emphasized by Besley and Persson (2014), political and economic processes of development create a feedback loop between governance quality, tax compliance, and government revenues. In this sense, the measure of institutional quality used in Section 6.3 is just a convenient way to group countries together into those with similar institutions for the purposes of estimation, rather than the demonstration of a causal explanation for the patterns of non-compliance.

In this section, we provide further exploratory evidence on the correlates of our estimated compliance gaps. To do so, we regress the estimated domestic compliance gaps from Section 6.3 on measures of economic and political institutions, while controlling for countries' level of economic development. Specifically, we estimate regressions of the following form where $\widehat{\gamma}_{i}$ is the domestic compliance from section 6.3. inst $t_{i}$ is a measure of economic and/or political institutions, $\beta^{\text {ins }}$ is an coefficient to be estimated, $\mathbf{X}_{i}$ is a vector of control variables, $\beta^{\prime}$ is a vector of coefficients, and $\zeta_{i}$ is an error term:

$$
\widehat{\gamma}_{i}=\beta_{0}+\beta^{\text {ins }} \text { inst }_{i}+\beta^{\prime} \mathbf{X}_{i}+\zeta_{i} .
$$

We again emphasize that these cross-sectional regressions should not be given a causal interpretation. Nevertheless, the relationship between estimated gaps and national institutional factors in the cross-section helps us to understand and evaluate some of the theories about tax compliance

37We therefore exclude from the figure countries where imports exceed one hundred percent of final consumption, since our model would imply a negative compliance gap in those cases. 
Table 7: Conditional Correlates of Estimated Compliance Gaps

\begin{tabular}{|c|c|c|c|c|c|c|c|}
\hline & $\begin{array}{c}\text { Threshold } \\
\text { (1) }\end{array}$ & $\begin{array}{l}\text { Starting } \\
\text { Business } \\
\text { (2) }\end{array}$ & $\begin{array}{c}\text { Ease of } \\
\text { Business } \\
\text { (3) }\end{array}$ & $\begin{array}{c}\text { Registering } \\
\text { Property } \\
\text { (4) }\end{array}$ & $\begin{array}{c}\text { Private } \\
\text { Credit } \\
\text { (5) }\end{array}$ & $\begin{array}{c}\text { Branches } \\
\text { (Demo) } \\
\text { (6) }\end{array}$ & $\begin{array}{c}\text { Branches } \\
\text { (Geo) } \\
(7)\end{array}$ \\
\hline$\widehat{\beta}^{\text {ins }}$ & $\begin{array}{c}0.012 \\
(0.016)\end{array}$ & $\begin{array}{c}0.012 \\
(0.020)\end{array}$ & $\begin{array}{l}0.051^{* *} \\
(0.020)\end{array}$ & $\begin{array}{l}0.032^{*} \\
(0.016)\end{array}$ & $\begin{array}{c}-0.075^{* * *} \\
(0.027)\end{array}$ & $\begin{array}{l}-0.006 \\
(0.025)\end{array}$ & $\begin{array}{c}0.005 \\
(0.015)\end{array}$ \\
\hline Controls & Yes & Yes & Yes & Yes & Yes & Yes & Yes \\
\hline $\begin{array}{l}\text { Observations } \\
\text { R-squared }\end{array}$ & $\begin{array}{c}71 \\
0.705\end{array}$ & $\begin{array}{c}73 \\
0.695\end{array}$ & $\begin{array}{c}73 \\
0.713\end{array}$ & $\begin{array}{c}73 \\
0.709\end{array}$ & $\begin{array}{c}47 \\
0.622\end{array}$ & $\begin{array}{c}47 \\
0.567\end{array}$ & $\begin{array}{c}47 \\
0.567\end{array}$ \\
\hline
\end{tabular}

Notes: This table presents estimates of equation (16). Each column is a different regression with the variable in the column title used for inst $_{i}$. Standard errors are in parentheses. ${ }^{* * *} \mathrm{p}<0.01,{ }^{* *} \mathrm{p}<0.05,{ }^{*} \mathrm{p}<0.1$. The dependent variable in all regressions is $\widehat{\gamma}_{i}$ as derived in section 6.3 All regressions include a cubic in (log) GDP per capita, and the control of corruption index. Observations are weighted by the index of the standard error of $\widehat{\gamma}_{i}$ derived in section 6.3. The number of observations is not constant due to the unavailability of some proxies for inst $_{i}$ for certain countries. Results are unchanged when using a constant number of observations.

that have been advanced in the past, and may help to inform future research on determinants of tax compliance.

We estimate equation (16) using seven different measures of economic and/or political institutions with results appearing in table 7 . Each column represents a different regression where the measure of institutions used for inst $_{i}$ is in the column title. In all specifications, inst $_{i}$ is normalized by its standard deviation allowing coefficients to be comparable across columns. We also control for countries' level of economic development by including a cubic polynomial in log GDP per capita as well as the control of corruption index $w_{i}$ used in section 6.3 to ensure that we are not just picking up a correlation between $w_{i}$ and $i_{s} t_{i}$. We weight observations by the inverse of the standard error of $\widehat{\gamma}_{i}$ generated by the delta method to take into account the fact that $\gamma_{i}$ is a generated regressand with a known standard error. While the sample changes across columns due to the availability of the relevant right hand side variable, qualitative results are unchanged with a constant sample.

One potential concern is that our estimates may simply reflect the exemption from VAT available to small traders in many countries, which in effect leads small firms to pay tax on inputs including imports rather than on outputs destined to final consumption. Small trader exemptions may indeed lead to losses in VAT revenues, but this should be reflected in the policy gap for VAT, rather than the compliance gap per se. To investigate the role of small trader exemptions, column (1) regresses estimated compliance gaps on the log of each country's turnover threshold above which firms must legally register for VAT, expressed as a fraction of log GDP per capita $3^{38}$ Column (1) shows a higher registration threshold is in fact associated with a high compliance gap, but this effect is small and insignificant suggesting that small firm exemptions do not drive our results overall.

$3^{8}$ These threshold values are listed in the Appendix. 
Of course, other institutional factors may affect the distribution of firm size within countries and the incentives to establish formal businesses that may be subject to VAT, rather than small informal business that are generally exempt. As a further check on these concerns, column (2) regress the compliance gap estimates on the score inversely related to the costs of starting a business, as measured in the 2018 Doing Business (DB) survey published by the World Bank. Klapper et al. (2006) have shown that measures of entry regulations of this kind can partially explain differences across countries in the rate of incorporation, the average size of entrant firms, and the growth rate of incumbent firms. Again, however, this measure is unrelated to our compliance gap.

More generally, DB scores measure a broader variety of regulatory frictions that may impede business development and therefore limit job creation, growth, and poverty reduction. But research using the DB indicators has not generally examined the possible countervailing role of business regulation in improving tax compliance and increasing tax collection efficiency. Indeed, many regulations coded in the DB indicators as frictions actually represent taxes imposed on businesses or regulatory filing requirements intended to improve tax compliance. As one example, the 2018 Doing Business report notes that "Botswana made registering property more difficult by adding a requirement to notify the tax agency of the value added tax payment." 39 Besley (2015) emphasizes this point, arguing that "there is more to having a good tax system than ease of compliance. The Doing Business indicators would measure the burdens imposed on firms, but from a social perspective, any gains in revenue-raising efficiency would need to be balanced against such costs." In short, there may exist a tradeoff in designing regulatory institutions between facilitating growth of firms and assurance of tax compliance.

To investigate this possibility, column (3) regresses the estimated compliance gaps on the aggregate score from the Doing Business database for "Ease of doing business." The coefficient is positive suggesting that, in countries where it is easier to do business, compliance gaps are larger. Following the example of Botswana, column (4) examines whether the ease of registering property is a correlate of compliance and finds that it is: countries in which it is easier to register property tend to have higher compliance gaps.

Lastly, we turn to how financial development may affect tax compliance. Several authors have suggested that tax enforcement is easier, and tax compliance greater, when tax authorities may obtain information on firm-level transactions through financial intermediaries, rather than from taxpayers themselves (e.g. Beck et al., 2014). Based on these considerations, Gordon and Li (2009) argue that compliance may be lower in countries where the financial sector is less developed, and agents can use cash in place of intermediated transactions in order to evade taxes. To begin to get at this issue, we follow Beck et al. (2014) and use private credit to GDP as recorded in the

\footnotetext{
39https://www.doingbusiness.org/content/dam/doingBusiness/country/b/botswana/BWA.pdf, pg. 62.
} 
International Financial Statistics of the IMF as a measure of financial development 40 Consistent with these arguments, credit development is negatively associated with the estimated compliance gap (column 5). However, as Beck et al. (2014) point out, private credit is only a rough measure for the breadth of the financial system, and to what degree tax authorities may obtain information on firm-level transactions through financial intermediaries. For this reason, we use to additional measures advocated by Beck et al. (2014): $i$ ) the number of bank branches per 1,000,00o adults [Branch (demo)] and $i$ i) branches per 10,000 square kilometers [Branch (geo)]. We are not arguing that these measures are necessarily superior to private credit, but rather they may provide useful robustness checks. We find that the results pertaining to financial depth are not robust to these measures (columns 6 and 7). Consequently, we find mixed evidence on the role of the financial sector in generating our compliance gaps, but we emphasize that none of our measures are perfect measures that might come from an ideal thought experiment of some countries being randomized into recording their financial transactions while others work more with cash-based transactions let alone being exogenously and randomly determined.

Overall, we find mixed evidence regarding correlates of our gaps. We find no evidence that the size of the informal sector nor VAT thresholds are a significant correlate of our estimated gaps. However, we find some evidence that more lax regulatory environments are correlated with higher compliance gaps, and mixed evidence for the role of the financial sector.

\section{Concluding remarks}

Economists believe that institutions related to state and fiscal capacity are important for tax compliance and revenue, and that tax revenues in turn can yield improvements in state and fiscal capacity generating a positive feedback loop for economic development. That said, we lack reliable, comparable estimates which speak to the importance of non-compliance in explaining differences in revenue across countries.

This paper provides a new method of estimating value added tax revenues lost due to domestic non-compliance using aggregate time series data available for a large set of countries, and shows how estimated non-compliance depends on state and civil society institutions. It relies on the insight that, because VAT compliance tends to be higher at borders, the correlation between VAT revenue performance (i.e. C-efficiency) and shares of imports in final consumption is informative about the extent of VAT non-compliance on domestic production.

Our results suggest that domestic compliance varies widely across countries. It is especially low in countries with low measures of control of corruption and in countries in Africa, Asia, Latin America, and Eastern Europe. In contrast, in countries with higher measured institutional quality

\footnotetext{
${ }^{40}$ Data for columns (5)-(7) are from table 1 of Beck et al. (2014).
} 
and in those countries in Northern Europe, domestic compliance is much higher. As well, we find that countries which import larger shares of imports in final consumption tend to have higher aggregate compliance due to controls at international borders. As such, our results speak to the importance of international trade as an institution that fosters state capacity to raise revenues.

While our results speak to the importance of border controls in promoting fiscal capacity, we abstract from welfare effects in our analysis. A formal cost-benefit analysis of VAT taxes versus trade taxes may offer normative results. However, we believe that this first bit of evidence on using trade and VAT performance to understand domestic non-compliance is a first step in that direction. 


\section{A Appendix}

\section{A.1 Sample}

\begin{tabular}{|c|c|c|c|c|c|}
\hline Country & Years & $\begin{array}{l}\text { In EU } \\
\text { In EU }\end{array}$ & $\begin{array}{c}\text { Threshold } \\
\text { (USD) }\end{array}$ & $\begin{array}{c}\text { Standard } \\
\text { Rate }\end{array}$ & $\begin{array}{c}\text { Import } \\
\text { VAT Rate }\end{array}$ \\
\hline Albania & $2005-2016$ & $\mathrm{O}$ & 47403 & 20 & . \\
\hline Argentina & 2002-2004 & $\mathrm{O}$ & $\mathrm{o}$ & 21 & . \\
\hline Armenia & $2004-2015$ & $\mathrm{o}$ & 140291 & 20 & . \\
\hline Australia & 2000-2016 & $\mathrm{O}$ & 67606 & 10 & 8.400 \\
\hline Austria & $1995-2016$ & 1 & $\mathrm{o}$ & 20 & . \\
\hline Azerbaijan & 2008-2015 & $\mathrm{o}$ & 28709 & 18 & 11.90 \\
\hline Barbados & $2003-2004$ & $\mathrm{O}$ & 40000 & 15 & . \\
\hline Belarus & $2003-2016$ & $\mathrm{o}$ & o & 20 & . \\
\hline Belgium & $1995-2016$ & 1 & 19933 & 21 & 18 \\
\hline Bolivia & 2002-2007 & $\mathrm{o}$ & o & 13 & 12.50 \\
\hline Bosnia and Herzegovina & $2011-2016$ & $\mathrm{O}$ & 33917 & 17 & . \\
\hline Bulgaria & $1995-2016$ & 1 & 33971 & 20 & . \\
\hline Cabo Verde & 2008-2009 & $\mathrm{o}$ & o & 15 & 8.700 \\
\hline Canada & $1995-2016$ & $\mathrm{o}$ & 27122 & 5 & 3.900 \\
\hline Chile & $2000-2016$ & $\mathrm{o}$ & $\mathrm{O}$ & 19 & 16.10 \\
\hline China & $2005-2015$ & $\mathrm{o}$ & $\mathrm{o}$ & 17 & 10.10 \\
\hline Congo, Republic of & $2003-2012$ & $\mathrm{o}$ & . & 18 & . \\
\hline Costa Rica & 2000-2015 & $\mathrm{o}$ & $\mathrm{o}$ & 13 & . \\
\hline Croatia & 2002-2014 & 1 & 39968 & 25 & . \\
\hline Cyprus & $1995-2016$ & 1 & 20730 & 19 & 13 \\
\hline Czech Republic & $1995-2016$ & 1 & 48175 & 21 & . \\
\hline Denmark & $1995-2016$ & 1 & 8909 & 25 & 24.90 \\
\hline El Salvador & $2002-2016$ & $\mathrm{o}$ & $\mathrm{O}$ & 13 & 10 \\
\hline Estonia & $1995-2016$ & 1 & 21244 & 20 & $\cdot$ \\
\hline Finland & $1995-2016$ & 1 & 13288 & 24 & $24 \cdot 30$ \\
\hline France & $1995-2016$ & 1 & 109231 & 20 & 17.20 \\
\hline Georgia & $2003-2016$ & $\mathrm{o}$ & 56655 & 18 & . \\
\hline Germany & $1991-2016$ & 1 & 23255 & 19 & . \\
\hline Greece & $1995-2016$ & 1 & $\mathrm{o}$ & 23 & . \\
\hline Honduras & $2003-2015$ & $\mathrm{o}$ & $\mathrm{o}$ & 15 & . \\
\hline
\end{tabular}




\begin{tabular}{|c|c|c|c|c|c|}
\hline Hungary & $1995-2016$ & 1 & $\mathrm{O}$ & 27 & . \\
\hline Iceland & $1998-2016$ & $\mathrm{o}$ & $\mathrm{O}$ & 24 & 17.80 \\
\hline Indonesia & $2008-2016$ & $\mathrm{O}$ & $\mathrm{O}$ & 10 & . \\
\hline Ireland & $1995-2016$ & 1 & 99505 & 23 & $5 \cdot 700$ \\
\hline Israel & $1995-2016$ & $\mathrm{o}$ & 22215 & 17 & . \\
\hline Italy & $1995-2016$ & 1 & o & 22 & . \\
\hline Japan & $1994-2015$ & $\mathrm{o}$ & 94389 & 8 & 6.200 \\
\hline Kazakhstan & $2000-2016$ & $\mathrm{o}$ & 167 & 12 & 8.100 \\
\hline Kenya & $2014-2015$ & $\mathrm{O}$ & 56868 & 16 & $7 \cdot 500$ \\
\hline Korea & $2007-2015$ & $\mathrm{O}$ & $\mathrm{o}$ & 10 & 9 \\
\hline Kyrgyz Republic & $2014-2016$ & $\mathrm{O}$ & . & 12 & . \\
\hline Latvia & $1995-2016$ & 1 & 66442 & 21 & . \\
\hline Lesotho & $2003-2007$ & $\mathrm{o}$ & 78381 & 14 & . \\
\hline Lithuania & $1995-2016$ & 1 & 59846 & 21 & . \\
\hline Macedonia, FYR & 2006-2007 & $\mathrm{o}$ & 43137 & 18 & . \\
\hline Malta & $1996-2016$ & 1 & $\mathrm{o}$ & 18 & . \\
\hline Mauritius & 2009-2016 & $\mathrm{O}$ & 130430 & 15 & 8.800 \\
\hline Moldova & $2002-2016$ & $\mathrm{O}$ & 42748 & 20 & 12.20 \\
\hline Morocco & $2002-2011$ & $\mathrm{o}$ & 237916 & 20 & 16.10 \\
\hline Netherlands & $1995-2016$ & 1 & 2502 & 21 & . \\
\hline New Zealand & $1997-2015$ & $\mathrm{O}$ & 49839 & 15 & 15.10 \\
\hline Norway & $1995-2016$ & $\mathrm{o}$ & 7934 & 25 & 20.60 \\
\hline Paraguay & $2005-2016$ & $\mathrm{O}$ & $\mathrm{O}$ & 10 & . \\
\hline Peru & $1995-2016$ & $\mathrm{O}$ & $\mathrm{O}$ & 16 & 14.80 \\
\hline Poland & $1995-2016$ & 1 & 47542 & 23 & . \\
\hline Portugal & $1995-2016$ & 1 & 13288 & 23 & . \\
\hline Romania & $1995-2016$ & 1 & 19412 & 20 & 11.40 \\
\hline Russia & $2002-2016$ & $\mathrm{O}$ & $\mathrm{O}$ & 18 & 12.30 \\
\hline Rwanda & 2014-2016 & $\mathrm{O}$ & 29307 & 18 & . \\
\hline Serbia & $2007-2012$ & $\mathrm{O}$ & 90492 & 18 & . \\
\hline Seychelles & $2012-2016$ & $\mathrm{O}$ & 156912 & 15 & . \\
\hline Slovak Republic & $1995-2016$ & 1 & 66110 & 20 & 13.30 \\
\hline Slovenia & $1999-2016$ & 1 & 66442 & 22 & . \\
\hline South Africa & $1997-2016$ & $\mathrm{O}$ & 92213 & 14 & 12.10 \\
\hline Spain & $1995-2016$ & 1 & $\mathrm{o}$ & 21 & 17 \\
\hline Sweden & $1995-2016$ & 1 & $\mathrm{O}$ & 25 & 15.20 \\
\hline
\end{tabular}




\begin{tabular}{lccccc} 
Switzerland & $1995-2016$ & 0 & 109152 & 8 & $4 \cdot 300$ \\
Thailand & $2000-2016$ & 0 & 55419 & 7 &. \\
Tunisia & $2008-2012$ & 0 & 58904 & 18 &. \\
Turkey & $2008-2016$ & 0 & 0 & 18 &. \\
Uganda & $2015-2016$ & 0 & 19232 & 18 &. \\
Ukraine & $2002-2016$ & 0 & 83397 & 20 &. \\
United Kingdom & $1995-2016$ & 1 & 133349 & 20 & 11.80 \\
Uzbekistan & $2011-2016$ & 0 & 0 & 20 &. \\
\hline
\end{tabular}

\section{A.2 Interpreting the Estimating Equation With Fixed Effects}

This section shows how we can still recover estimates of the parameters of interest when there are country fixed effects. Start with the estimating equation where we impose $\gamma$ to be the same across countries within some group but allow $\pi_{i t}$ to vary by country and time:

$$
E_{i t}=(1-\gamma)\left(1-\pi_{i t}\right)+\gamma\left(1-\pi_{i t}\right) \mu_{i t}
$$

where $\mu_{i t}=M_{i t} / C_{i t}$. This heterogeneity in the policy gap is the source of the errors in our regression. Now assume that we can decompose $\pi_{i}$ into an average effect, a country deviation from that average, and a country-year deviation from $\pi$ and $\pi_{i t}$ :

$$
\pi_{i t}=\pi+\pi_{i}+\epsilon_{i t}^{\pi}
$$

We assume that $\pi \equiv \sum_{i, t} \pi_{i t} / N$ where $N$ is the number of observations in the sample. It follows that both $\pi_{i}$ and $\epsilon_{i t}^{\pi}$ are mean zero ${ }^{41} \epsilon_{i t}^{\pi}$ do not need to be i.i.d. random noise. Combining equations (17) and (18), we obtain:

$$
E_{i t}=(1-\gamma)(1-\pi)+\gamma(1-\pi) \mu_{i t}-\gamma \pi_{i} \mu_{i t}+\nu_{i}+\epsilon_{i t}
$$

where

$$
\epsilon_{i t} \equiv-\mu_{i t} \epsilon_{i t}^{\pi} \quad \text { and } \quad \nu_{i} \equiv-(1-\gamma) \pi_{i}
$$

Each of these is mean zero by construction. However, even under classic OLS assumptions, there may be an omitted variable bias if countries with higher policy gaps are more or less open (i.e.

\footnotetext{
${ }^{41}$ Making $\pi_{i}$ a linear function of a vector of observables $\mathbf{x}_{i}$ does not change any of what follows as long as these covariates are mean zero.
} 
$\left.\operatorname{cov}\left[\pi_{i}, \mu_{i t}\right] \neq 0\right)$. If we define within-country means using bars, we can obtain

$$
\bar{E}_{i}=(1-\gamma)(1-\pi)+\gamma(1-\pi) \bar{\mu}_{i}-\gamma \pi_{i} \bar{\mu}_{i}+\nu_{i}+\bar{\epsilon}_{i}
$$

Subtracting $\bar{E}_{i}$ from $E_{i t}$, we obtain

$$
E_{i t}-\bar{E}_{i}=\gamma(1-\pi)\left(\mu_{i t}-\bar{\mu}_{i}\right)-\gamma \pi_{i}\left(\mu_{i t}-\bar{\mu}_{i}\right)+\epsilon_{i t}-\bar{\epsilon}_{i} .
$$

Our same orthogonality condition will hold that a regression of $E_{i t}-E_{i}$ on $\left(\mu_{i t}-\bar{\mu}_{i}\right)$ will return an unbiased estimate of $\gamma(1-\pi)$ if the covariance of $\mu_{i t}-\bar{\mu}_{i}$ and $\pi_{i}$ is zero (i.e. more open countries do not have systematically different policy gaps. We then define the pooled average of C-efficiency using double bars (except for $\bar{v}$ which represents the average of $\nu_{i}$ across countries) :

$$
\overline{\bar{E}}=(1-\gamma)(1-\pi)+\gamma(1-\pi) \overline{\bar{\mu}}-\gamma \overline{\pi \bar{\mu}}+\bar{\nu}+\overline{\bar{\epsilon}}
$$

Adding this back in to equation (19), we obtain

$$
E_{i t}-E_{i}+\bar{E}=(1-\gamma)(1-\pi)+\gamma(1-\pi)\left(\mu_{i t}-\bar{\mu}_{i}+\overline{\bar{\mu}}\right)-\gamma \pi_{i}\left(\mu_{i t}-\bar{\mu}_{i}\right)-\gamma \overline{\pi \bar{\mu}}+\bar{\nu}+\epsilon_{i t}-\bar{\epsilon}_{i}+\overline{\bar{\epsilon}} .
$$

All terms on the left are data and estimates of $(1-\gamma)(1-\pi)$ and $\gamma(1-\pi)$ can be obtained by regressing the data on the left hand side on $\mu_{i t}-\bar{\mu}_{i}+\overline{\bar{\mu}}$. Under the previous stated assumptions, the last four terms are either zero or mean zero. We also require there is no correlation between $\pi_{i}$ and $\left(\mu_{i t}-\bar{\mu}_{i}\right)$ so that $\overline{\pi \bar{\mu}}=0$ in expectation. Lastly, if $\pi_{i}$ and $\mu_{i}$, are uncorrelated, the fourth term will be mean zero and uncorrelated with $\left(\mu_{i t}-\bar{\mu}_{i}-\overline{\bar{\mu}}\right)$. OLS will recover estimates of $(1-\gamma)(1-\pi)$ and $\gamma(1-\pi)$, and then $\gamma$ and $\pi$ can then be obtained using the delta method. Addition of time fixed effects is straightforward but more algebraically involved. 


\section{References}

Agha, Ali and Jonathan Haughton, "Designing Vat Systems: Some Efficiency Considerations," Review of Economics and Statistics, 1996, 78 (2), 303-308.

Almunia, Miguel, Jonas Hjort, Justine Knebelmann, and Lin Tian, "Strategic or Confused Firms? Evidence from "missing" transactions in UgandaâĞd'," Technical Report, Working Paper 2019.

Bachas, Pierre, Lucie Gadenne, and Anders Jensen, “Consumption Taxes with Informality: Theory and Cross-Country Evidence from Expenditure Diaries," Technical Report, Warwick University 2019.

Barbone, Luca, Misha Belkindas, Leon Bettendorf, Richard Bird, Mikhail Bonch-Osmolovskiy, and Michael Smart, "Study to quantify and analyse the VAT Gap in the EU-27 Member States," Technical Report, CASE-Center for Social and Economic Research 2013.

Baunsgaard, Thomas and Michael Keen, "Tax revenue and (or?) trade liberalization," Journal of Public Economics, 2010, 94 (9-10), 563-577.

Beck, Thorsten, Chen Lin, and Yue Ma, "Why do firms evade taxes? The role of information sharing and financial sector outreach," Journal of Finance, 2014, 69 (2), 763-817.

Benzarti, Youssef and Dorian Carloni, "Who really benefits from consumption tax cuts? Evidence from a large VAT reform in France," American Economic Journal: Economic Policy, 2019, 11 (1), 38-63.

Besley, Timothy, "Law, regulation, and the business climate: The nature and influence of the World Bank Doing Business project," Journal of Economic Perspectives, 2015, 29 (3), 99-120.

_ and Torsten Persson, Pillars of prosperity: The political economics of development clusters, Princeton University Press, 2011.

_ and _ , "Why do developing countries tax so little?," Journal of Economic Perspectives, 2014, 28 (4), 99-120.

Bird, Richard and Michael Smart, "Financing social expenditures in developing countries: Payroll or value added taxes," in Carmen Pagés, Jamele Rigolini, and David Robalino, eds., Social Insurance, Informality, and Labor Markets: How to Protect Workers While Creating Good Jobs, Oxford University Press, 2014.

Canada Revenue Agency, "Estimating and Analyzing the Tax Gap Related to the Goods and Services Tax/Harmonized Sales Tax," 2016. 
Dharmapala, Dhammika and James R Hines, "Which countries become tax havens?," Journal of Public Economics, 2009, 93 (9-10), 1058-1068.

Ebrill, Liam, Michael Keen, Jean-Paul Bodin, and Victoria Summers, The modern VAT, International Monetary Fund, 2001.

Emran, M Shahe and Joseph E Stiglitz, "On selective indirect tax reform in developing countries," Journal of Public Economics, 2005, 89 (4), 599-623.

Gadenne, Lucie, Tushar K Nandi, and Roland Rathelot, "Taxation and Supplier Networks: Evidence from India," Technical Report, Working Paper 2018.

Gordon, Roger and Wei Li, "Tax structures in developing countries: Many puzzles and a possible explanation," Journal of public Economics, 2009, 93 (7-8), 855-866.

Kaufmann, Daniel, Aart Kraay, and Massimo Mastruzzi, Governance matters VIII: Aggregate and individual governance indicators 1996-2008, The World Bank, 2009.

Keen, Michael, “VAT attacks!," International Tax and Public Finance, 2007, 14 (4), 365-381.

_ , "VAT, tariffs, and withholding: Border taxes and informality in developing countries," Journal of Public Economics, 2008, 92 (10-11), 1892-1906.

_ , "The anatomy of the VAT," National Tax Journal, 2013, 66 (2), 423.

- and Ben Lockwood, "The value added tax: Its causes and consequences," Journal of Development Economics, 2010, 92 (2), 138-151.

Klapper, Leora, Luc Laeven, and Raghuram Rajan, "Entry regulation as a barrier to entrepreneurship," Journal of financial economics, 2006, 82 (3), 591-629.

Lockwood, Ben and Giuseppe Migali, "Did the single market cause competition in excise taxes? Evidence from EU countries," The Economic Journal, 2009, 119 (536), 406-429.

Paula, Aureo De and Jose A Scheinkman, "Value-added taxes, chain effects, and informality," American Economic Journal: Macroeconomics, 2010, 2 (4), 195-221.

Piggott, John and John Whalley, "VAT base broadening, self supply, and the informal sector," American Economic Review, 2001, 91 (4), 1084-1094.

Pomeranz, Dina, "No taxation without information: Deterrence and self-enforcement in the value added tax," American Economic Review, 2015, 105 (8), 2539-69. 
Reckon, LLP, "Study to quantify and analyse the VAT gap in the EU-25 Member States," Report for DG Taxation and Customs Union, September, 2009.

Slemrod, Joel, "Tax compliance and enforcement," Technical Report, National Bureau of Economic Research 2018.

Smart, Michael, "Departures from Neutrality in Canada's Goods and Services Tax," University of Calgary SPP Research Papers, 2012, 5 (5).

Timmer, Marcel, Abdul A Erumban, Reitze Gouma, Bart Los, Umed Temurshoev, Gaaitzen J de Vries, Iñaki Arto, Valeria Genty, Frederik Neuwahl, Joseph Francois et al., "The world input-output database (WIOD): contents, sources and methods," Technical Report, Institue for International and Development Economics 2012.

Ueda, Junji, "The Evolution of Potential VAT Revenues and C-Efficiency in Advanced Economies," Working Paper WP/17/158, International Monetary Fund 2017.

van Brederode, Robert and Pierre-Pascal Gendron, "The taxation of cross-border interstate sales in federal or common markets," World Journal of VAT/GST Law, 2013, 2 (1), 1-23. 


\section{Oxford University Centre for Business Taxation Working Paper series recent papers}

WP 20/06 Peter Morrow, Michael Smart and Artur Swistak VAT Compliance, Trade, and Institutions

WP 20/05 Daniel J.Hemel and David A.Weisbach The Behavioral Elasticity of Tax Revenue

WP 20/04 Daniel Shaviro What are Minimum Taxes and Why Might One Favor or Disfavor Them?

WP20/03 Aqib Aslam and Alpa Shah Tec(h)tonic Shifts: Taxing the "Digital Economy"

WP20/02 Ronald B. Davies, Dieter F. Kogler and Ryan Hynes Patent Boxes and the Success Rate of Applications

WP20/01 Richard Collier, Alice Pirlot and John Vella Tax policy and the COVID-19 crisis

WP19/16 Alice Pirlot Don't blame it on WTO law: An analysis of the alleged WTO law incompatibility of Destination-Based Taxes

WP19/15 Irem Güçeri and Maciej Albinowski Investment Responses to Tax Policy under Uncertainty

WP19/14 David R. Agrawal and David E. Wildasin Technology and Tax Systems

WP19/13 Alice Pirlot Exploring the Impact of European Union Law on Energy and Environmental Taxation

WP19/12 Michael Devereux How should business profit be taxed? Some thoughts on conceptual developments during the lifetime of the IFS

WP19/11 Sarah Clifford and Panos Mavrokonstantis Tax Enforcement using a Hybrid between Self- and Third-Party Reporting

WP19/10 Miguel Almunia, Irem Guceri, Ben Lockwood, Kimberley Scharf More giving or more givers? The effects of tax incentives on charitable donations in the UK

WP19/09 Itai Grinberg Stabilizing "pillar one" corporate profit reallocation in an uncertain environment

WP19/08 Joel Slemrod, Obeid Ur Rehman, Mazhar Waseem Pecuniary and non-pecuniary motivations for tax compliance: evidence from Pakistan

WP19/07 Enda Hargaden, Barra Roantree Does statutory incidence matter? Earnings responses to social security contributions 
WP19/06 Lucie Gadenne, Tushar K. Nandi, Roland Rathelot Taxation and supplier networks: evidence from India

WP19/05 Thiess Buettner, Boryana Madzharova Unit sales and price effects of preannounced consumption tax reforms: micro-level evidence from European VAT

WP19/04 Katarzyna Bilicka, Yaxuan Qi, Jing Xing Debt reallocation in multinational firms: evidence from the UK worldwide debt cap

WP19/03 Reuven Avi-Yonah, Orli Avi-Yonah, Nir Fishbien and Haiyan Xu Bridging the redblue divide: a proposal for US Regional Tax Relief

WP19/02 Elizabeth Gugl, George R. Zodrow Tax competition and the efficiency of "benefitrelated" business taxes

WP19/01 Michael P Devereux, Alan Auerbach, Michael Keen, Paul Oosterhuis, Wolfgang Schön and John Vella Residual profit allocation by income

WP18/22 Ronny Freier, Martin Simmler and Christian Wittrock Public good provision, commuting and local employment

WP18/21 Christian Wittrock Localization Economies and the Sensitivity of Firm Foundations to Changes in Taxation and Public Expenditures

WP18/20 Nadine Riedel, Martin Simmler and Christian Wittrock Local fiscal policies and their impact on the number and spatial distribution of new firms

WP18/19 Leonie Hug and Martin Simmler How cost-effective is public R\&D in stimulating firm innovation?

WP18/18 Wiji Arulampalam and Andrea Papini Tax Progressivity and Self-Employment Dynamics

WP18/17 Wiji Arulampalam, Michael P Devereux and Federica Liberini Taxes and the Location of Targets

WP18/16 Frank M Fossen, Ray Rees, Davud Rostam-Afschaf and Viktor Steiner How do Entrepreneurial Portfolios Respond to Income Taxation

WP18/15 Sebastian Beer, Ruud de Mooij and Li Liu International Corporate Tax Avoidance: A Review of the Channels, Magnitudes and Blind Spots

WP18/14 Daisy Ogembo Are Presumptive Taxes a Good Option for Taxing Self-Employed Professionals in Developing Countries

WP18/13 Ilan Benshalom The Rise of Inequality and the fall of Tax Equity 
WP18/12 Thomas Torslov, Ludwig Weir and Gabriel Zucman The Missing Profits of Nations

WP18/11 Andrea Lassman and Benedikt Zoller-Rydzek Decomposing the Margins of Transfer Pricing

WP18/10 Travis Chow, Jeffrey L Hoopes and Edward L Maydew US Firms on Foreign (tax) Holidays

WP18/09 Claudio Agostini, Juan Pablo Atal and Andrea Repetto Firms Response to Tax Enforcement through Audits

WP18/08 Mazhar Waseem Information, Asymmetric Incentives or Withholding? Understanding the Self-Enforcement of Value-Added-Tax

WP18/07 Matthew Smith, Danny Yagan, Owen Zidar and Eric Zwick Capitalists in the twenty-first century

WP18/06 Daniel Shaviro The new non-territorial U.S international tax system

WP18/05 Eric M Zolt Tax Treaties and Developing Countries

WP18/04 Anne Brockmeyer, Marco Hernandez, Stewart Kettle and Spencer Smith Casting a wider tax net: Experimental evidence from Costa Rica

WP18/03 Ruud de Mooij and Li Liu At a cost:the real effects of transfer pricing regulations

WP18/02 Rita de la Feria Tax fraud and the rule of law

WP18/01 Eddy Hiu Fung Tam Behavioural response to time notches in transaction tax: Evidence from stamp duty in Hong Kong and Singapore

WP17/19 Michael P. Devereux, Giorgia Maffini and Jing Xing Corporate tax incentives \& capital structure: New evidence from UK firm-level tax returns

WP17/18 Sarah Clifford Taxing Multinationals beyond borders: financial and locational responses to CFC rules

WP17/17 Dominik von Hagen and Axel Prettl Controlled foreign corporation rules and crossborder M\&A activity

WP17/16 Marie Lamensch Destination based taxation of corporate profits - preliminary findings regarding tax collection in cross-border situations

WP17/15 Li Liu Tim Schmidt-Eisenlohr and Dongxian Guo International transfer pricing and tax avoidance: Evidence from linked trade-tax statistics in the UK. 
WP17/14 Katarzyna Habu How much tax do companies pay in the UK?

WP17/13 Katarzyna Habu How aggressive are foreign multinational companies in reducing their corporation tax liability?

WP17/12 Edward D. Kleinbard The right tax at the right time

WP17/11 Aaron Flaaen The role of transfer prices in profit-shifting by U.S. multinational firms: Evidence from the 2004 Homeland Investment Act

WP17/10 Ruud de Mooij and Li Liu At a cost: The real effect of transfer pricing regulations on multinational investments

WP17/09 Wei Cui Taxation without information: The institutional foundations of modern tax collection

WP17/08 John Brooks The definitions of income

WP17/07 Michael P. Devereux and John Vella Implications of Digitalization for International Corporation Tax Reform

WP17/06 Richard Collier and Michael P. Devereux The Destination-Based Cash Flow Tax and the Double Tax Treaties

WP17/05 Li Liu Where does multinational investment go with Territorial Taxation

WP17/04 Wiji Arulampalam, Michael P Devereux and Federica Liberini Taxes and Location of Targets

WP17/03 Johannes Becker and Joachim Englisch A European Perspective on the US plans for a Destination based cash flow tax

WP17/02 Andreas Haufler, Mohammed Mardan and Dirk Schindler Double tax discrimination to attract FDI and fight profit shifting: The role of CFC rules

WP17/01 Alan Auerbach, Michael P. Devereux, Michael Keen and John Vella Destinationbased cash flow taxation

WP16/14 Anzhela Cédelle The EU Anti-Tax Avoidance Directive: A UK Perspective

WP16/13 Michael Devereux Measuring corporation tax uncertainty across countries:

Evidence from a cross-country survey

WP16/12 Andreas Haufler and Ulf Maier Regulatory competition in capital standards with selection effects among banks

WP16/11 Katarzyna Habu Are financing constraints binding for investment? Evidence from natural experiment 
WP 16/10 Li Liu and Ben Lockwood VAT notches, voluntary registration and bunching: Theory and UK evidence

WP 16/09 Harry Grubert and Roseanne Altshuler Shifting the burden of taxation from the corporate to the personal level and getting the corporate tax rate down to 15 percent

WP 16/08 Margaret K McKeehan and George R Zodrow Balancing act: weighing the factors affecting the taxation of capital income in a small open economy

WP 16/07 Michael P Devereux and Li Liu Stimulating investment through incorporation

WP 16/06 Stephen R Bond and Irem Guceri R\&D and productivity: Evidence from large UK establishments with substantial $R \& D$ activities

WP16/05 Tobias Böhm, Nadine Riedel and Martin Simmler Large and influential: firm size and governments' corporate tax rate choice?

WP16/04 Dhammika Dharmapala The economics of corporate and business tax reform

WP 16/03 Rita de la Feria EU VAT principles as interpretative aids to EU VAT rules: the inherent paradox

WP 16/02 Irem Guceri Will the real R\&D employees please stand up? Effects of tax breaks on firm level outcomes

WP 16/01 Giorgia Maffini, Jing Xing and Michael P Devereux The impact of investment incentives: evidence from UK corporation tax returns

WP 15/33 Anzhela Cédelle Enhanced co-operation: a way forward for tax harmonisation in the EU?

WP 15/32 James Mahon and Eric Zwick Do experts help firms optimise?

WP 15/31 Robin Boadway, Motohiro Sato and Jean-François Tremblay Cash-flow business taxation revisited: bankruptcy, risk aversion and asymmetric information

WP 15/30 Martin Simmler Do multinational firms invest more? On the impact of internal debt financing and transfer pricing on capital accumulation

WP 15/29 Daniel Shaviro The crossroads versus the seesaw: getting a 'fix' on recent international tax policy developments

WP 15/28 Zhonglan Dai, Douglas A Shackelford, Yue (Layla) Ying and Harold H Zhang Do companies invest more after shareholder tax cuts? 
WP 15/27 Martin Ruf and Julia Schmider Who bears the cost of taxing the rich? An empirical study on CEO pay

WP 15/26 Eric Orhn The corporate investment response to the domestic production activities deduction

WP 15/25 Li Liu International taxation and MNE investment: evidence from the UK change to territoriality

WP 15/24 Edward D Kleinbard Reimagining capital income taxation

WP 15/23 James R Hines Jr, Niklas Potrafke, Marina Riem and Christoph Schinke Inter vivos transfers of ownership in family firms

WP 15/22 Céline Azémar and Dhammika Dharmapala Tax sparing agreements, territorial tax reforms, and foreign direct investment

WP 15/21 Wei Cui A critical review of proposals for destination-based cash-flow corporate taxation as an international tax reform option

WP 15/20 Andrew Bird and Stephen A Karolyi Governance and taxes: evidence from regression discontinuity

WP 15/19 Reuven Avi-Yonah Reinventing the wheel: what we can learn from the Tax Reform Act of 1986

WP 15/18 Annette Alstadsæter, Salvador Barrios, Gaetan Nicodeme, Agnieszka Maria Skonieczna and Antonio Vezzani Patent boxes design, patents, location and local R\&D

WP 15/17 Laurent Bach Do better entrepreneurs avoid more taxes?

WP 15/16 Nadja Dwenger, Frank M Fossen and Martin Simmler From financial to real economic crisis: evidence from individual firm-bank relationships in Germany

WP 15/15 Giorgia Maffini and John Vella Evidence-based policy-making? The Commission's proposal for an FTT

WP 15/14 Clemens Fuest and Jing Xing How can a country 'graduate' from procyclical fiscal policy? Evidence from China?

WP 15/13 Richard Collier and Giorgia Maffini The UK international tax agenda for business and the impact of the OECD BEPS project

WP 15/12 Irem Guceri and Li Liu Effectiveness of fiscal incentives for R\&D: quasiexperimental evidence 
WP 15/11 Irem Guceri Tax incentives and R\&D: an evaluation of the 2002 UK reform using micro data

WP 15/10 Rita de la Feria and Parintira Tanawong Surcharges and penalties in UK tax law

WP 15/09 Ernesto Crivelli, Ruud de Mooij, Michael Keen Base erosion, profit-shifting and developing countries

WP 15/08 Judith Freedman Managing tax complexity: the institutional framework for tax policy-making and oversight

WP 15/07 Michael P Devereux, Giorgia Maffini and Jing Xing Corporate tax incentives and capital structure: empirical evidence from UK tax returns

WP 15/06 Li Liu and Ben Lockwood VAT notches

WP 15/05 Clemens Fuest and Li Liu Does ownership affect the impact of taxes on firm behaviour? Evidence from China.

WP 15/04 Michael P Devereux, Clemens Fuest and Ben Lockwood The taxation of foreign profits: a unified view

WP 15/03 Jitao Tang and Rosanne Altshuler The spillover effects of outward foreign direct investment on home countries: evidence from the United States

WP 15/02 Juan Carlos Suarez Serrato and Owen Zidar Who benefits from state corporate tax cuts? A local labour markets approach with heterogeneous firms

WP 15/01 Ronald B Davies, Julien Martin, Mathieu Parenti and Farid Toubal Knocking on Tax Haven's Door: multinational firms and transfer pricing 